\title{
Bulk Shielding Facility Quarterly Report April, May, and June of 1975
}

\author{
S. S. Hurt, III \\ E. D. Lance \\ J.R. Thomas
}

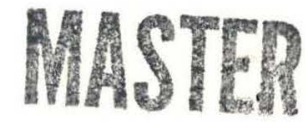

\section{OAK RIDGE NATIONAL LABORATORY}

OPERATED BY UNION CARBIDE CORPORATION • FOR THE U.S. ATOMIC ENERGY COMMISSION 


\section{DISCLAIMER}

This report was prepared as an account of work sponsored by an agency of the United States Government. Neither the United States Government nor any agency Thereof, nor any of their employees, makes any warranty, express or implied, or assumes any legal liability or responsibility for the accuracy, completeness, or usefulness of any information, apparatus, product, or process disclosed, or represents that its use would not infringe privately owned rights. Reference herein to any specific commercial product, process, or service by trade name, trademark, manufacturer, or otherwise does not necessarily constitute or imply its endorsement, recommendation, or favoring by the United States Government or any agency thereof. The views and opinions of authors expressed herein do not necessarily state or reflect those of the United States Government or any agency thereof. 


\section{DISCLAIMER}

Portions of this document may be illegible in electronic image products. Images are produced from the best available original document. 
Printed in the United States of America. Available from National Technical Information Service

U.S. Department of Commerce

5285 Port Royal Road, Springfield, Virginia 22161

Price: Printed Copy $\$ 5.00$; Microfiche $\$ 2.25$

This report was prepared as an account of work sponsored by the United States Government. Neither the United States nor the Energy Research and Development Administration, nor any of their employees, nor any of their contractors, subcontractors, or their employees, makes any warranty, express or implied, or assumes any legal liability or responsibility for the accuracy, completeness or usefulness of any information, apparatus, product or process disclosed, or represents that its use would not infringe privately owned rights. 
Contract No. W-7405-eng-26

OPERATIONS DIVISION

BULK SHIELDING FACILITY QUARTERLY REPORT

APRIL, MAY, AND JUNE OF 1975

\section{JANUARY 1976}

S. S. Hurt, III

E. D. Lance

J. R. Thomas

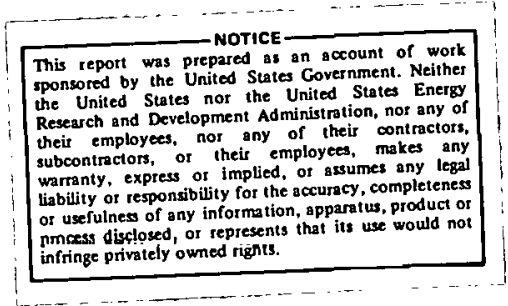

NOTICE:, This document contains information of a preliminary nature and was prepared-primarily for internal use at the Oak Ridge National Laboratory. It is subject to revision or correction and therefore does.not represent.a final report.

OAK RIDGE.. NATIONAL LABORATORY

Oak Ridge, Tennessee 37830

operated by

UNION CARBIDE CORPORATION

for the

ENERGY RESEARCH AND DEVELOPMENT ADMINISTRATION 
THIS PAGE

WAS INTENTIONALLY

LEFT BLANK 
CONTENTS

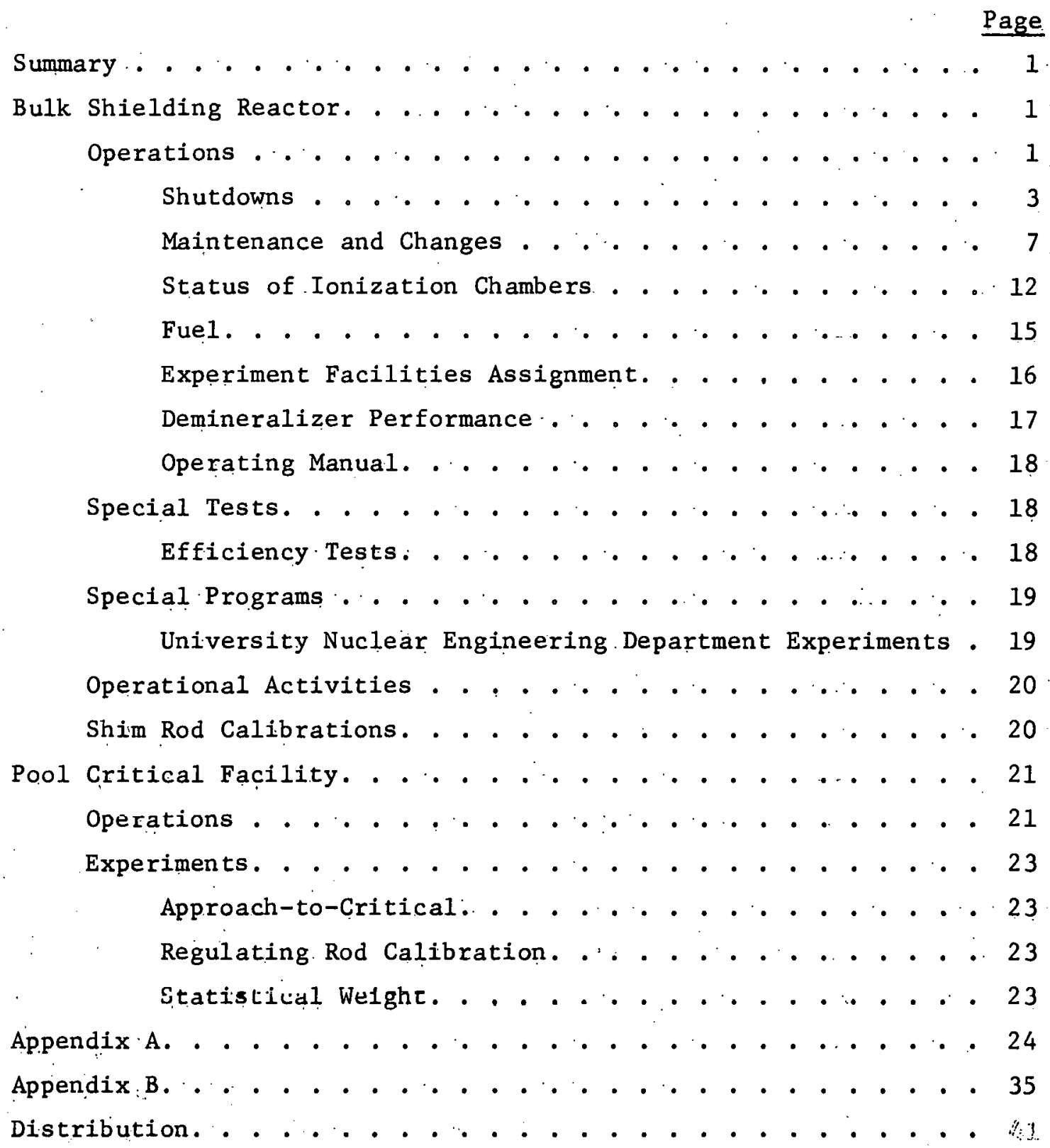


FIGURE LIST

Dwg. or Photo No.

Caption

$\underline{\text { Page }}$

Fig. 1. Core Loading 26 - BSR

4

Fig. 2. Core Loading 27 - BSR

5

Fig. 3. Core Loading 28 - BSR

6

Appendix A. Calibration of BSR Shim Rods

24

No. 1 Shim Rod - BSR

No. 2 Shim Rod - BSR

26

No. 3 Shim Rod - BSR

27

No. 4 Shim Rod - BSR

28

No. 5 Shim Rod - BSR

29

No. 6 Shim Rod - BSR

30

Nos. 1-4 Shim Rods - BSR

31

Nos. 5-6 Shim Rods - BSR

Nos. 1-6 Shim Rods - BSR

33

Reactivity Remaining in Shim Rods $1-4\left(\% \frac{\Delta \mathrm{k}}{\mathrm{k}}\right.$ 


\section{SUMMARY}

The BSR operated at an average power level of $1,722 \mathrm{kw}$ for $37.10 \%$ of the time during April, May, and June. Water-quality. control in both the reactor primary and secondary cooling systems was satisfactory.

The BSR was operated at low and variable power during this quarter for 91.566 hours as part of the training programs for nuclear engineering students from the University.. of. Tennessee and Mississippi State University.

The P.CA was also used in the abovementioned training programs and was operated on seven occasions. when the University of Kentucky or Mississippi State University students actively participated in training laboratories.

\section{BULK SHIELDING REACTOR}

Operations

During this quarter, the reactor operated $37.10 \%$ of the time primarily for the irradiation of research experiments. It was operated at. low and variable power ( $11.30 \%$ of the operating time) to enable nuclear engineering students from the University of Tennessee and Mississippi State University to perform training labs described elsewhere in this report. Basic operating data for this period are given in Table 1.

Table 1. Basic Operating Data

(April, May and June of 1975)

\begin{tabular}{|c|c|c|c|}
\hline & $\begin{array}{l}\text { This } \\
\text { Quarter }\end{array}$ & $\begin{array}{l}\text { :Last } \\
\text { Quarter }\end{array}$ & $\begin{array}{l}\text { Year } \\
\text { To Date }\end{array}$ \\
\hline Total engergy, kwd & 58,126 & $.116,948$ & $1.75,074$ \\
\hline $\begin{array}{l}\text { Average power, } \\
\text { kw/operating } h r\end{array}$ & 1,722 & 1,942 & 1,832 \\
\hline Time operating, $\%$ & 37.10 & 66.95 & 52.02 \\
\hline Reactor availability, \% & 82.77 & 90.23 & 86.50 \\
\hline $\begin{array}{l}\text { Reactor water radinactivity } \\
\text { counts } \min ^{-1} \mathrm{ml}^{-1} \text { (av) }\end{array}$ & 2,657 & 2,016 & 2,336 \\
\hline $\begin{array}{l}\text { Reactor water resistivicy, } \\
\text { ohm-cm (av) }\end{array}$ & 932,000 & $1,031,000$ & 982,000 \\
\hline $\begin{array}{l}\text { Standard. fuel elements } \\
\text { depleted }\end{array}$ & 1 & 4 & 5 \\
\hline $\begin{array}{l}\text { Control fuel elements } \\
\text { depleted }\end{array}$ & 2 & 0 & 2 \\
\hline Research samples & 28 & 17 & 45 \\
\hline
\end{tabular}


Core loading 26 (Figure 1).was temporarily.replaced..by core loading 27 (Figure. 2) on June. 12, .1975, for. special. flux mapping for a proposed heavy steel experiment. Core. loading $2.7 \mathrm{had}$ an operating mass of $4691 \mathrm{~g}$ which provided an excess reactivity of $5.20 \% . \Delta \mathrm{k}$. The core configuration was returned. to core...No.: 26 . on.. June $13,1975$.

Core loading...26..(Figure 1) was replaced. by core loading. 28 (Figure 3) on June $26, \ldots 19.75$, to provide adequate excess reactivity. for versatile operation. The initial operating. mass. (4192 g. ${ }^{235} \mathrm{U}$ ) of core loading 26 had been reduced to 4030 .g. due to. burnup, thereby reducing the excess reactivity from $5.70 \% . \Delta \mathrm{k}$ to $\sim 3.15 \Delta \mathrm{k} / \mathrm{k}$ ( $\sim 0.60 \%$ exces s reactivity above xenon equilibrium).

Core loading 28. was accomplished by replacing one depleted BSF-series fuel element.-with a. new..MTR-series fuel element and installing two new control rod.fuel-elements... Core-loading. 28.had an initial operating mass of 4168 . g-which provided an. excess reactivity. of $5.45 \% \Delta \mathrm{k} / \mathrm{k}(2.90 \% . \Delta \mathrm{k} / \mathrm{k}$ excess reactivity above xenon equilibrium). 
Shutdowns

There were no unscheduled..shutdowns during the quarter. Table 2 gives an analysis. of. the scheduled shutdowns.

Table 2.. Analysis of Shutdowns

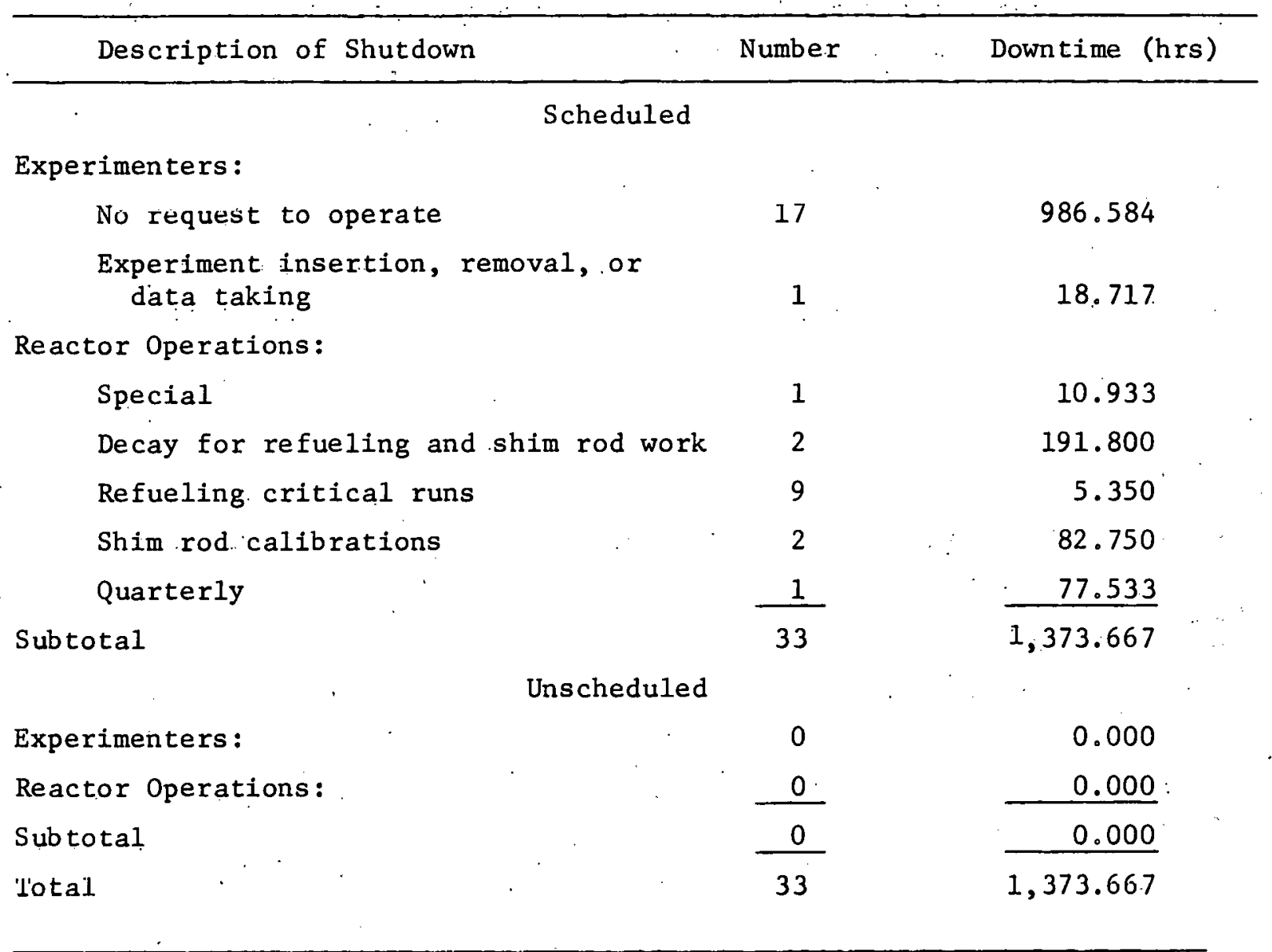




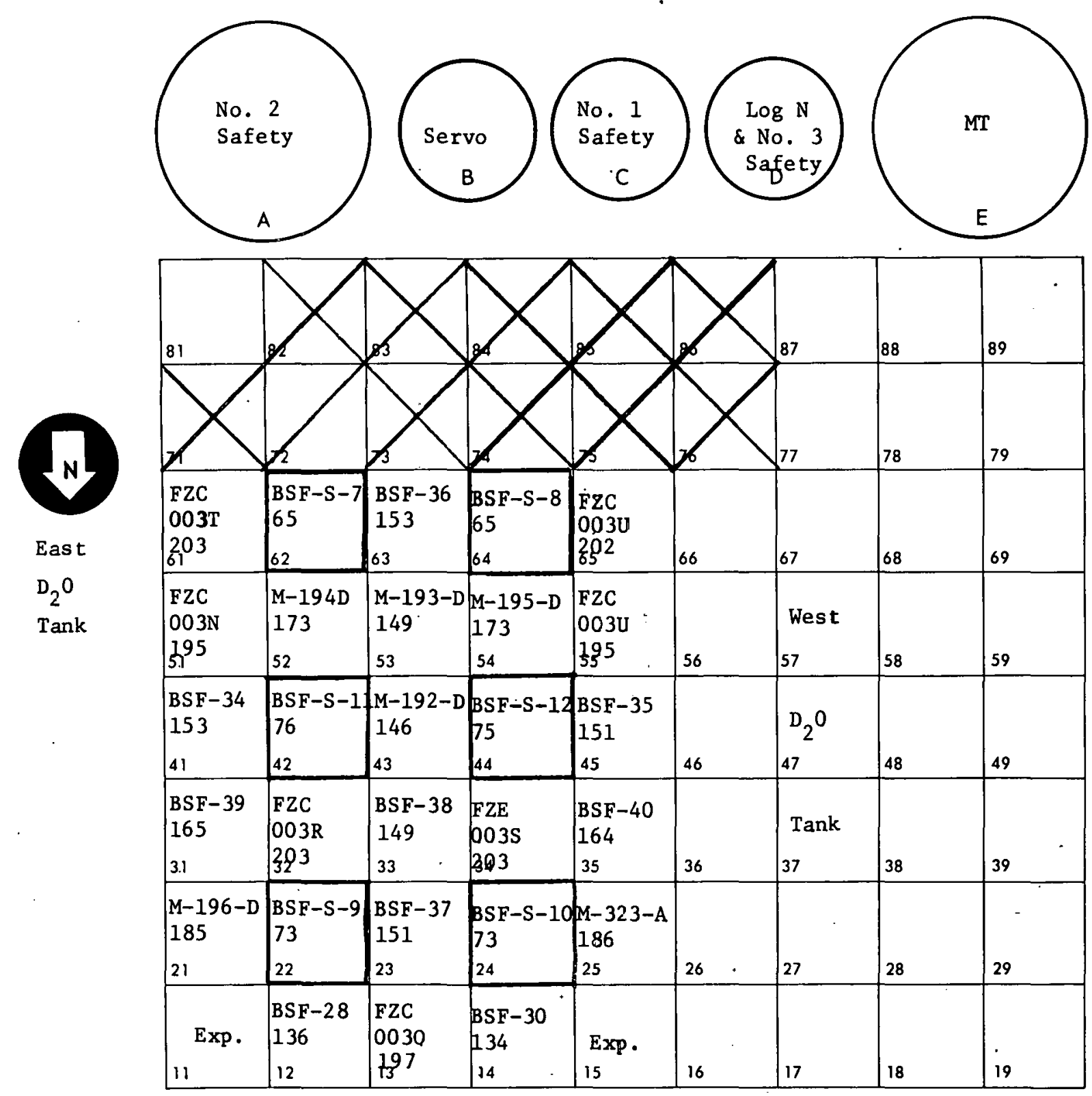

BSR CORE

$\cdot 26$

LOADING NO.

February 10, 1975

DATE

Excess Reactivity - $5.70 \%$ CRITICAL MASS

$\frac{4192}{\text { OPERATING MASS }}$

ROD POSITIONS AT CRITICAL (With Operating Moss)

\begin{tabular}{c|cc}
\hline ROD NO. & \multicolumn{2}{|c}{ IN. WITHDRAWN } \\
\hline 1 & 9.41 & 10.90 \\
\hline 2 & 9.41 & 10.90 \\
\hline 3 & 9.41 & 10.90 \\
\hline 4 & 9.41 & 10.90 \\
\hline 5 & 23.00 & 10.90 \\
\hline 6 & 23.00 & 10.90 \\
\hline REMARKS: & \multicolumn{2}{|c}{} \\
\hline
\end{tabular}

Fig. 1 Core Loading 26 - BSR

UCN-8504

(3) 1.68 ) 


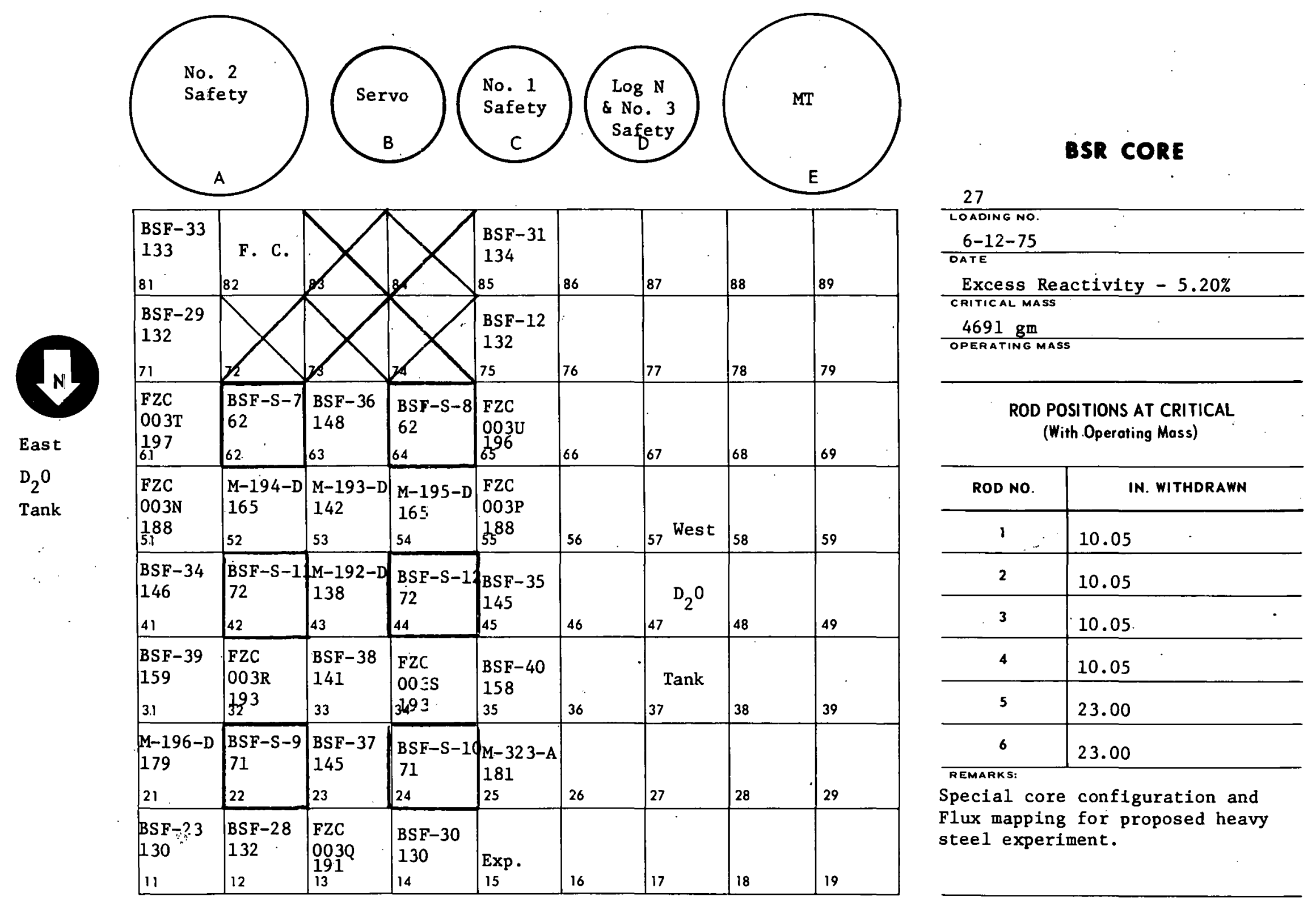

Figure 2. Core Loading 27 - BSR 


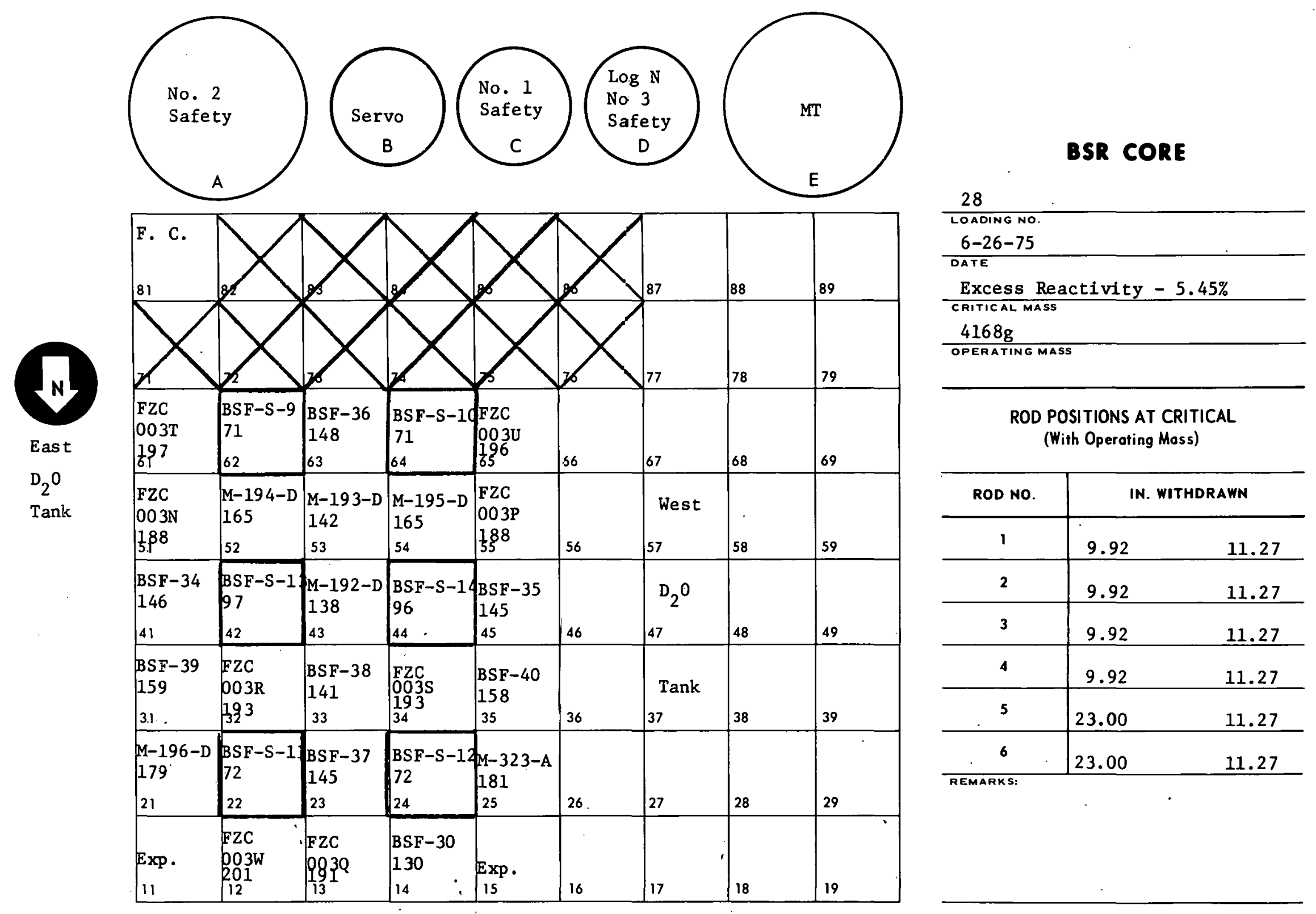

Figure 3. Care Loading $28-$ BSR 


\section{Maintenance and Changes.}

Changes made in the reactor control instrumentation to improve operating conditions are documented by the BSR control-change memoranda system. Those changes which were made during this report period are listed in.Table 3. Maintenance or changes on the instrumentation and mechanical components in the complex are listed in Tables 4 and 5 . Table 6 presents .the status of the ionization and fission chambers.

Tabile 3. Instrumentation and Controls Change, Memoranda Completed During This Report Period.

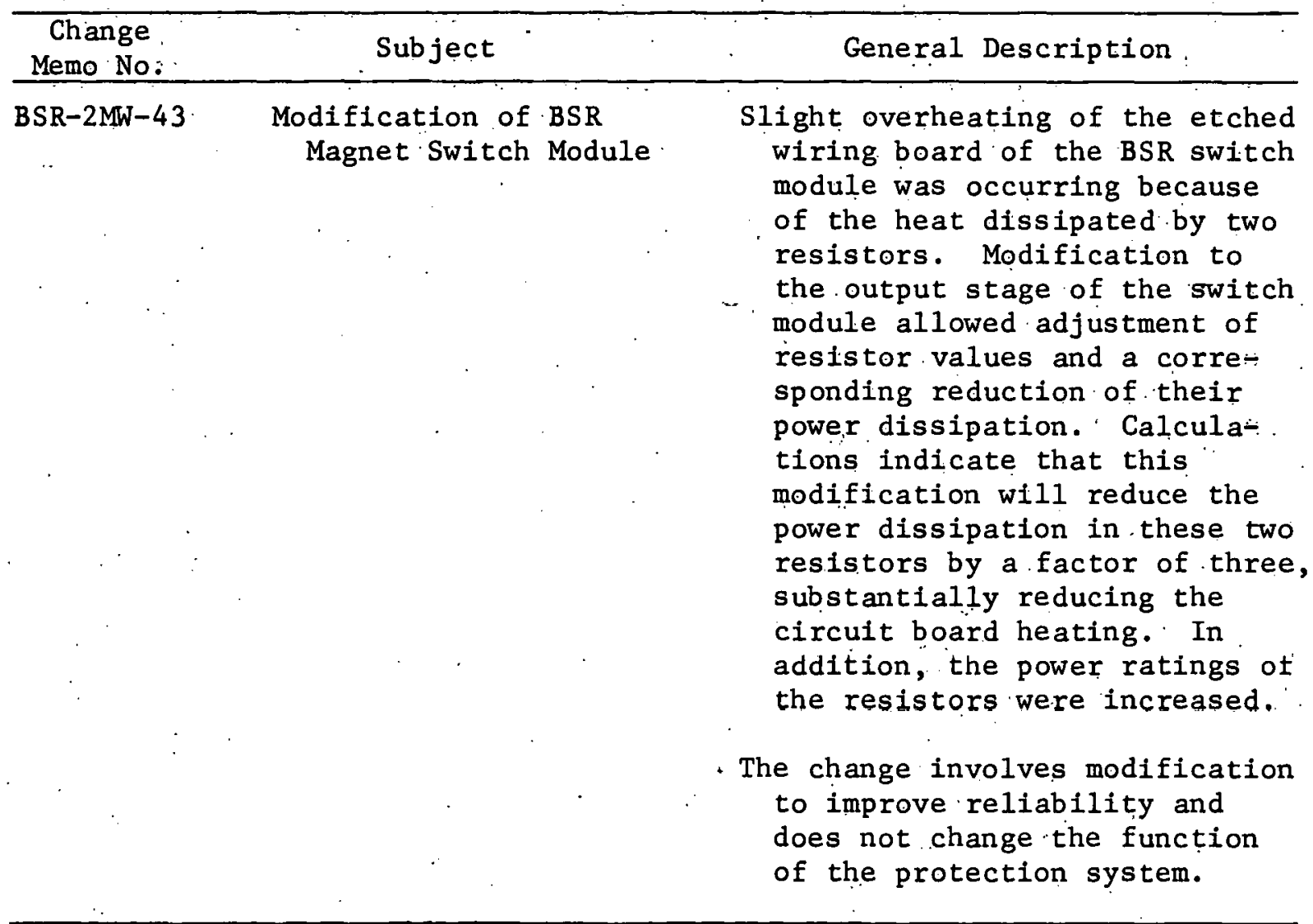


Table 4. Maintenance and Changes, Instrumentation and Controls

\begin{tabular}{|c|c|c|c|c|}
\hline Date & Component & Trouble or Change & Q. & Reason or Maintenance \\
\hline $4-3-75$ & $\begin{array}{l}\text { Facility radiation and } \\
\text { contamination monitoring } \\
\text { system }\end{array}$ & 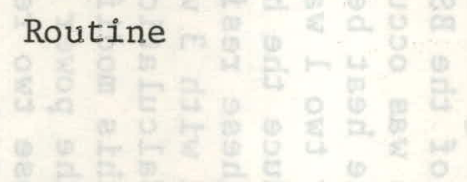 & & Quarterly checkout. \\
\hline $4-1-75$ & Servo ionization chamber & Routine checks $\frac{6}{4}=$ & & $\begin{array}{l}\text { Ionization characteristics checks } \\
\text { were completed on the servo } \\
\text { chamber. with satisfactory results. }\end{array}$ \\
\hline $\begin{array}{l}4-28-75 \\
\text { through } \\
4-30-75\end{array}$ & Instrumentation & 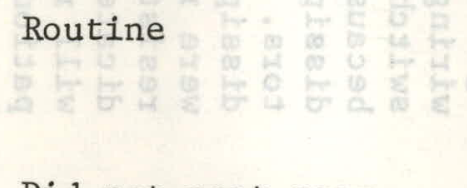 & & Quarterly checks. \\
\hline $4-30-75$ & $\begin{array}{l}\text { Nos. } 1 \text { and } 2 \text { sigma } \\
\text { amplifiers }\end{array}$ & $\begin{array}{l}\text { Did not meet spec- } \\
\text { ifications }\end{array}$ & & Replaced the 5692 electronic tubes. \\
\hline $4-30-75$ & No. 3 sigma amplifiers & Scram catcher inoperat & tive & Replaced the 6BN6 electronic tube. \\
\hline $5-12-75$ & $\begin{array}{l}\text { Dual ionization chamber } \\
\text { PCP-III-106, SN-66-1 }\end{array}$ & Chamber noisy & a & $\begin{array}{l}\text { The chamber was removed from position } \\
\text { B and placed in temporary storage } \\
\text { in the north pool area. }\end{array}$ \\
\hline $5-12-75$ & $\begin{array}{l}\text { Dual ionization chamber } \\
\text { PCP-III-106, SN-72-1 }\end{array}$ & Installed in position & B & $\begin{array}{l}\text { The new dual chamber was installed } \\
\text { in position B for the servo. } \\
\text { Saturation characteristics checks } \\
\text { were satisfactory. }\end{array}$ \\
\hline $5-21-75$ & $\begin{array}{l}\text { Servo on chamber power } \\
\text { supply }\end{array}$ & $\begin{array}{l}\text { Replaced one VR50 elec } \\
\text { tronic tube with VB } \\
\text { electronic tube }\end{array}$ & R150 & 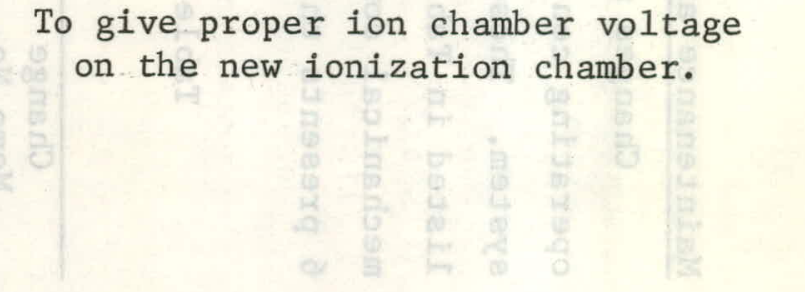 \\
\hline
\end{tabular}


Table 4. (continued)

\begin{tabular}{|c|c|c|}
\hline Date: & Compónient & Trouble or Change \\
\hline $6-2-.75$ & $\begin{array}{l}\text { Facility radiation and } \\
\text { contamination umon=' } \\
\text { itoring system }\end{array}$ & $\begin{array}{l}\text { False alarm received at } \\
\therefore \text { Emergency Control Center }\end{array}$ \\
\hline $6-5-75$ & $\begin{array}{l}\text { Facility radiation and } \\
\text { contamination monitoring } \\
\text { system. }\end{array}$ & Routine \\
\hline $\begin{array}{l}6-4-75 \\
6-9-75 \\
\text { and } \\
6-19-75\end{array}$ & $\begin{array}{l}\text { Magnet switch modulè } \\
\text { Nos. } 1,2,3,4,5 \text { and } \\
6\end{array}$ & $\begin{array}{l}\text { Made changes in accordance } \\
\text { with Reactor Instrument } \\
\text { \& Controls Design Change } \\
\text { Memo No. BSR-2MW- } 43\end{array}$ \\
\hline
\end{tabular}

Reason or Maintenance

The cause of the false alarm is being investigated.

The quarterly check was performed.

Slight overheating of the etched wiring board of the BSR switch module was occurring because of the heat dissipated by two resistors. Modification to the output stage of the switch module allowed adjustment of resistor values and a corresponding reduction of their power dissipation: Calculations indicate that this modification will reduce. the power dissipation in these two resistors by a factor of three, substantially reducing the circuit board heating." In addition, the power ratings of the resistors were increased.

The change involves modification to improve reliability and does not change the function of the protection system.

6-5-75 Secondary pH channe1. . Equipment updating

New underground signal leads and new $\mathrm{pH}$ probes were installed.

6-17-75 Ce11-ventilation system - Routine

The flow recorder was recalibrated. 
Table 5. Maintenance and Changes, Mechanical System

\begin{tabular}{|c|c|c|c|}
\hline Date & Component & Trouble or Change & Reas on or Maintenance \\
\hline $\begin{array}{l}6-23-75 \\
\text { through } \\
6-25-75\end{array}$ & $\begin{array}{l}\text { Shim-rod assemblies Nos. } \\
1,2,3,4,5 \text { and } 6\end{array}$ & Routine inspection & $\begin{array}{l}\text { The shim-rod assemblies were } \\
\text { removed to the underwater work } \\
\text { platform for inspection as } \\
\text { follows: Visual inspection - } \\
\text { no evidence of cracks; Straight } \\
\text { edge inspection - results sat- } \\
\text { isfactory; Gauged, using } 0.010 \\
\text { in. and } 0.020 \text { in. oversized } \\
\text { gauges and feeler gauges - } \\
\text { results satisfactory. Rust } \\
\text { was cleaned from the armatures } \\
\text { and magnets. The clutch switch- } \\
\text { es were cleaned and the guide } \\
\text { tubes brushed. See Appendix B } \\
\text { for a detailed inspection re- } \\
\text { port. }\end{array}$ \\
\hline $\begin{array}{l}6-23-75 \\
\text { through } \\
6-25-75\end{array}$ & $\begin{array}{l}\text { Shim-rod assembly No. } 1 \\
\text { from } \mathrm{CP}-22\end{array}$ & 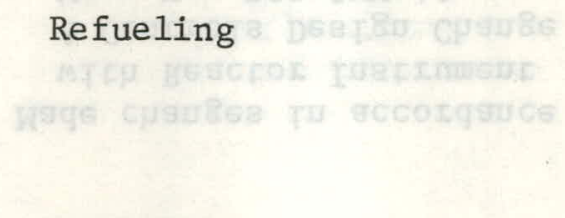 & $\begin{array}{l}\text { The assembly containing control- } \\
\text { rod fue } 1 \text { element BSF-S-9 was } \\
\text { transferred to CP- } 62 \text { to become } \\
\text { No. } 5 \text { shim rod. }\end{array}$ \\
\hline & $\begin{array}{l}\text { Shim-rod assemb1y No. } 2 \\
\text { from } \mathrm{CP}-24\end{array}$ & Rugriench countot couces & $\begin{array}{l}\text { The assembly containing control- } \\
\text { rod fuel element BSF-S-10 was } \\
\text { transferred to } \mathrm{CP}-64 \text { to become } \\
\text { No. } 6 \text { shim rod. }\end{array}$ \\
\hline $8-5-12$ & $\begin{array}{l}\text { Shim-rod assemb1y No. } 3 \\
\text { from CP- } 42\end{array}$ & Refueling & 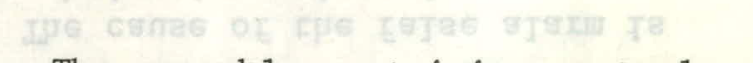 \\
\hline Dese & contononge & 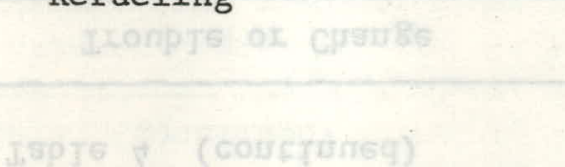 & $\begin{array}{l}\text { rod fuel element BSF-S- } 11 \text { was } \\
\text { transferred to } \mathrm{CP}-22 \text { to become } \\
\text { No. } 1 \text { shim rod. }\end{array}$ \\
\hline
\end{tabular}


Table. 5. (continued)

\begin{tabular}{|c|c|c|c|c|}
\hline Date... & Component & Trouble or & Change. & Reas.on : or Maintenance \\
\hline \multirow[t]{2}{*}{$\begin{array}{l}6-23-75 \\
\text { through } \\
6-25-75\end{array}$} & $\begin{array}{l}\text { Shim-rod assembly No. } 4 \\
\quad \text { from } C P-44\end{array}$ & Refueling & . & $\begin{array}{l}\text { The assembly containing control-rod } \\
\text { fuel. element BSF-S-12 was trans-: } \\
\text { ferred to } \mathrm{CP}-24 \text { to become No.' } 2 \\
\text { shim-rod. }\end{array}$ \\
\hline & $\begin{array}{l}\text { Shim-rod assembly No. } 5 \\
\text { from CP-62. }\end{array}$ & Refueling & . & $\begin{array}{l}\text { The spent control-rod fuel element } \\
\text { BSF-S-7. was replaced wïth a new. } \\
\text { element BSF-S-13 and the assembly } \\
\text { transferred to CP-42 to become No. } \\
3 \text { shim-rod: }\end{array}$ \\
\hline$\therefore$ & $\begin{array}{l}\text { Shim-rod assemb ly No. } 6 \\
\text { from CP- } 64\end{array}$ & Refueling & $:$ & $\begin{array}{l}\text { The spent control-rod fuel element } \\
\text { BSF-S-8 was replaced with a new } \\
\text { element BSF-S-14 and the assembly } \\
\text { transferred to } \mathrm{CP}-44 \text { to become } \\
\text { No. } 4 \text { shim-rod. }\end{array}$ \\
\hline
\end{tabular}


Table 6. Status. of Ionization Chambers

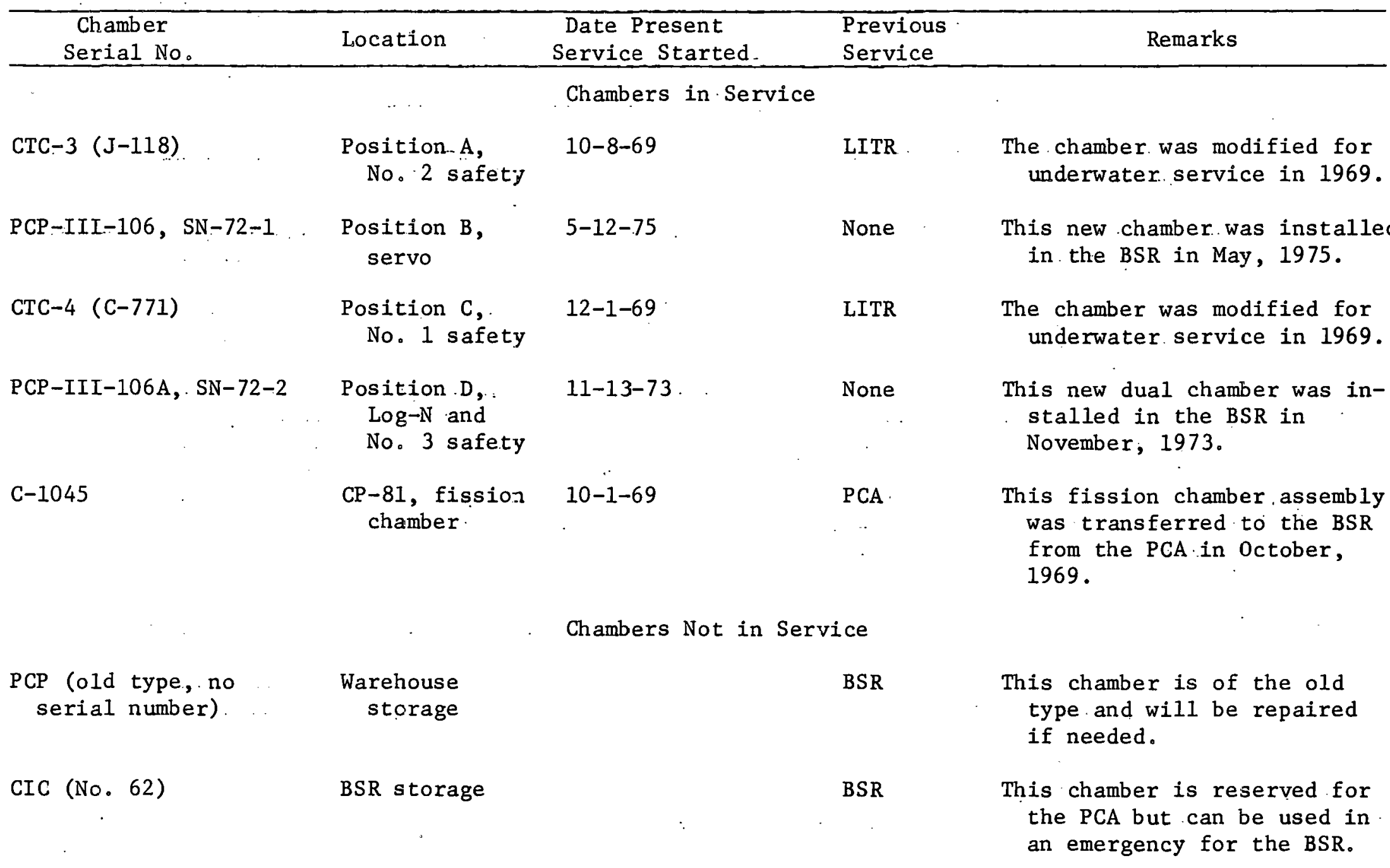


Table 6 (continued)

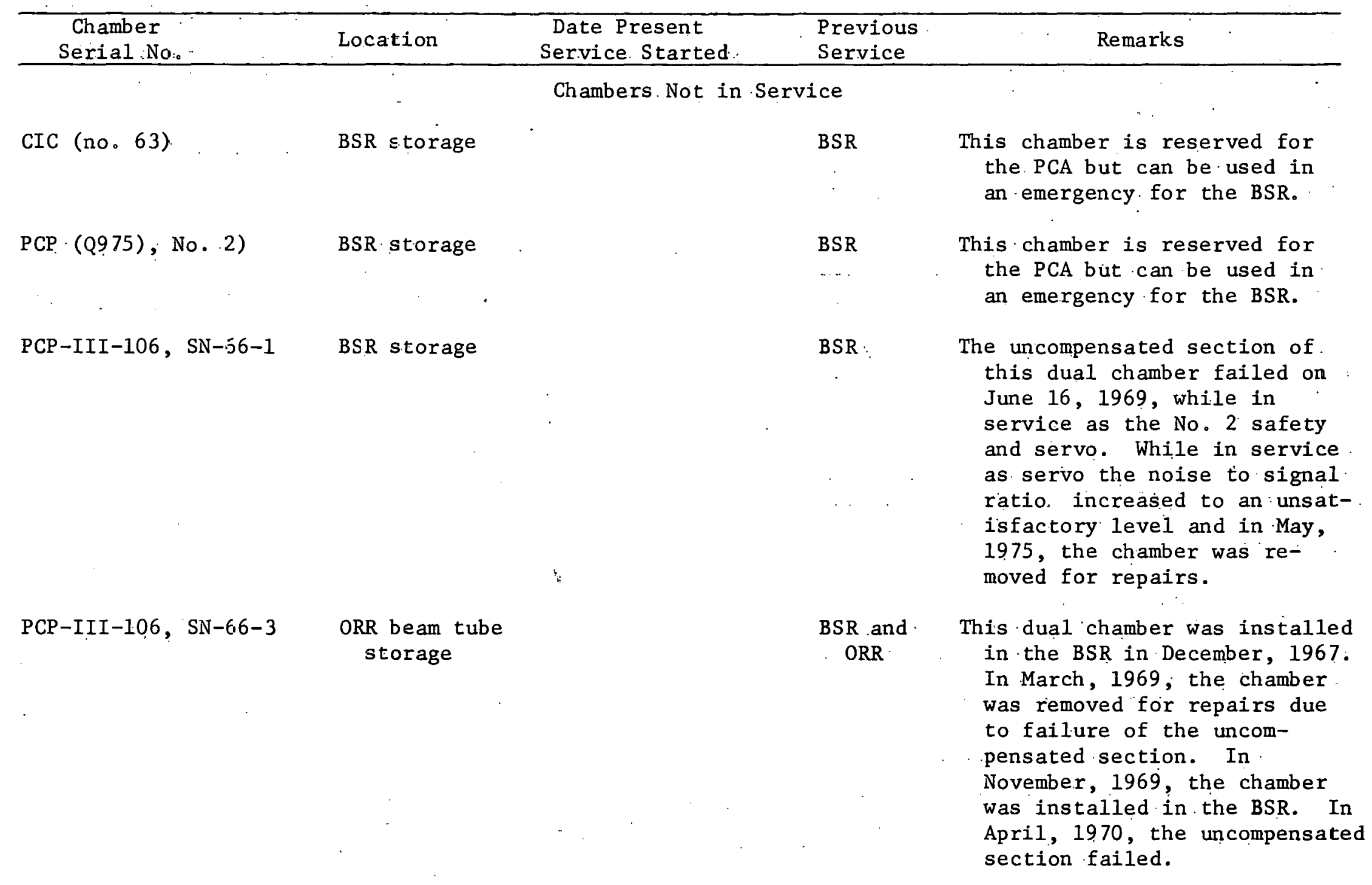


Table 6 (continued)

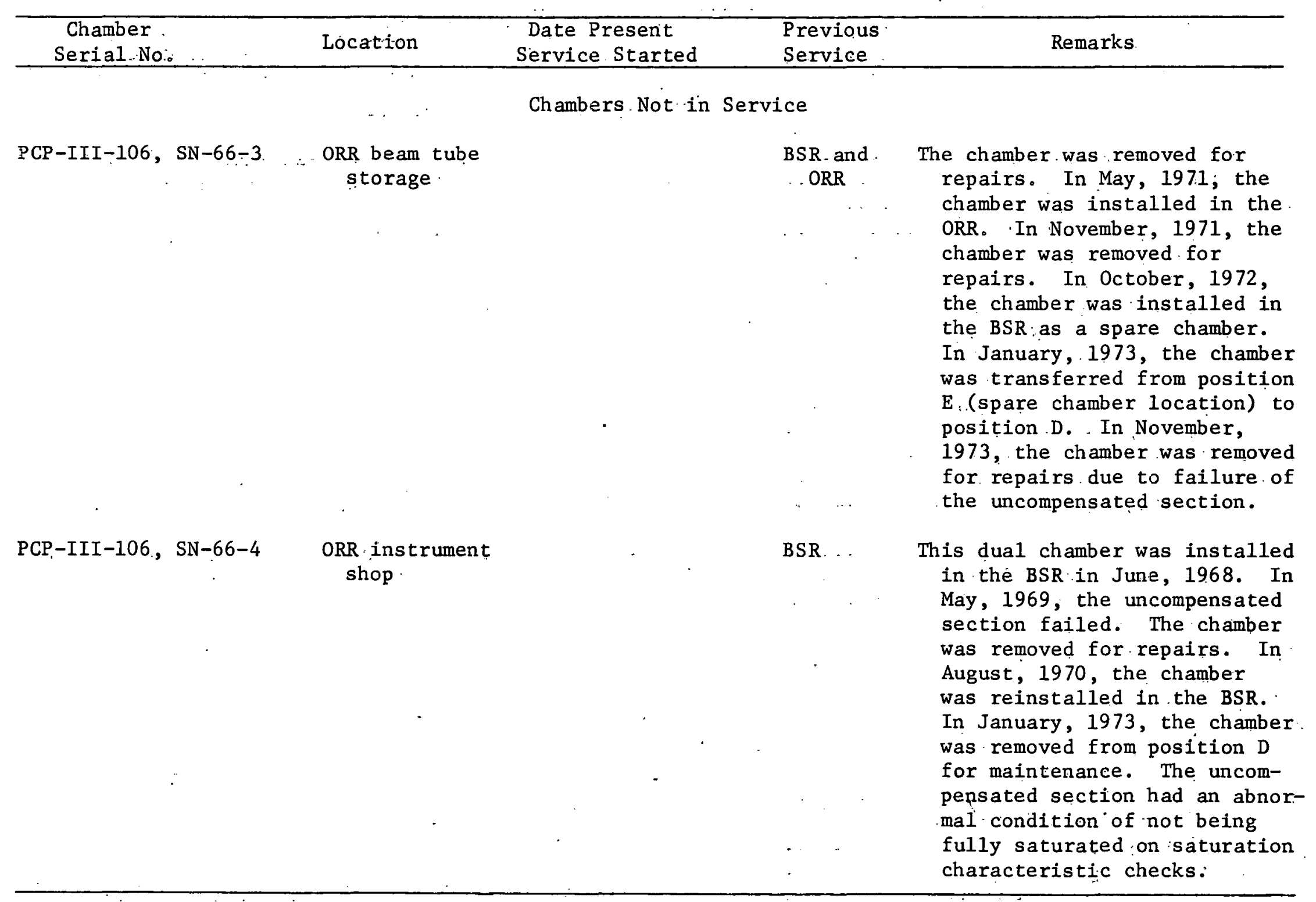


Fuel

Changes in the fuel inventory are reflected in Table 7.

Table 7. - Fuel and.Shim Rod Status

\begin{tabular}{|c|c|c|c|}
\hline & $\begin{array}{l}\text { This } \\
\text { Quarter }\end{array}$ & $\begin{array}{c}\text { Last } \\
\text { Quarter } \\
\end{array}$ & $\begin{array}{l}\text { Year } \\
\text { To Date }\end{array}$ \\
\hline Fuel elements depleted & 1 & 4 & 5 \\
\hline Control-rod fuel elements depleted & 2 & 0 & 2 \\
\hline New : fuel elements placed in service & 1 & 4 & 5 \\
\hline $\begin{array}{l}\text { New control-rod. fuel elements placed } \\
\text { in service }\end{array}$ & 2 & 0. & 2 \\
\hline New fuel elements available for use & 12 & 13 & 12 \\
\hline $\begin{array}{l}\text { New control-rod fuel elements } \\
\text { available for use }\end{array}$ & 6 & 8 & 6 \\
\hline $\begin{array}{l}\text { Partially depleted fuel elements } \\
\text { available for use }\end{array}$ & 0 & 0 & 0 \\
\hline New shim rods placed in service & 0 & 0 & 0 \\
\hline $\begin{array}{l}\text { Boron stainless steel shim rods in use } \\
\text { Boron stainless steel shim rods. } \\
\text { available for use. }\end{array}$ & 6 & 6 & 6 \\
\hline
\end{tabular}




\section{Experiment Facilities Assignment}

Facility assignments are listed in Table 8 . The tubes of the east $\mathrm{D}_{2} \mathrm{O}$ tank are not permanently assigned; they are used by various Laboratory personnel. for short-term sample-irradiations.

Table. 8. Facilities Assignment

\begin{tabular}{|c|c|c|}
\hline Facility & Location & $\begin{array}{c}\text { Division or } \\
\text { Sponsor }\end{array}$ \\
\hline Liquid helium cryostat & $\begin{array}{l}\text { Southwest corner of pool } \\
\text { using west } D_{2} 0 \text { tank }\end{array}$ & Solid State \\
\hline Liquid nitrogen cryostat & On instrument bridge & Solid State \\
\hline Ambient temperature facility. & North face of core & Solid State \\
\hline Front-face tube & North face of core & Solid State \\
\hline Fast-neutron tube & Core position 15 & Solid State \\
\hline Water-cooled tube & Core position 11 & Solid State \\
\hline Dry thermal-neutron tubes* & East $\mathrm{D}_{2} \mathrm{O}$ tank & Operations \\
\hline $\begin{array}{l}\text { Dry thermal-neutron tubes* } \\
\text { (east, center, southwest, } \\
\therefore \text { and northwest) }\end{array}$ & East $\mathrm{D}_{2} \mathrm{O}$ tank & Operations \\
\hline
\end{tabular}

\section{Demineralizer Performance}

Table 9 gives detailed information on the condition of the primary. water system. for.the preceding.year.and.pertinent data on the performance of the bypass demineralizer. 
Table 9. Demineralizer Performance Data

\begin{tabular}{|c|c|c|c|c|c|c|c|c|c|c|}
\hline \multirow{2}{*}{$\begin{array}{l}\text { Run } \\
\text { No. }\end{array}$} & \multirow{2}{*}{$\begin{array}{c}\text { Initiation } \\
\text { Date } \\
\end{array}$} & \multirow{2}{*}{\multicolumn{2}{|c|}{$\begin{array}{c}\text { Termination } \\
\text { Date }\end{array}$}} & \multirow{2}{*}{$\begin{array}{l}\text { Through put } \\
\text { (gal.) }\end{array}$} & \multirow{2}{*}{\multicolumn{2}{|c|}{ 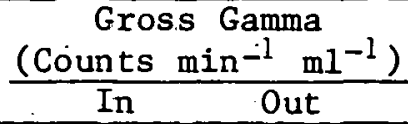 }} & \multicolumn{2}{|c|}{$\mathrm{pH}$} & \multicolumn{2}{|c|}{$\begin{array}{c}\text { Specific Resistance } \\
(\mathrm{ohm}-\mathrm{cm})\end{array}$} \\
\hline & & & & & & & In & Out & In & Out \\
\hline 33 & $1-4-73$ & & $3-5-73$ & $1,614,000$ & 1,280 & 115 & 5.7 & 5.8 & $1,008,000$ & $1,430,000$ \\
\hline 34 & $3-6-73$ & & $4-30-73$ & $1,393,200$ & 1,848 & 181 & 5.7 & 5.7 & 873,000 & $1,363.000$ \\
\hline 35 & $5-2-73$ & & $7-2-73$ & $2,060,000$ & 2,072 & 120 & 5.8 & 5.8 & 896,000 & $1,209,000$ \\
\hline 36 & $7-3-7.3$ & & $9-4-73$ & $1,900,000$ & 1,672 & 116 & 5.8 & 5.8 & 792,000 & $1,270,000$ \\
\hline 37 & $9-4-73$ & & $11-12-73$ & $1,300,000$ & 2,021 & 107 & 5.9 & 6.0 & 682,000 & $1,144,000$ \\
\hline 38 & $11-14-73$ & & $1-7-74$ & $1,692,000$ & 1,353 & 98 & 5.7 & 5.7 & 738,000 & $1,102,000$ \\
\hline 39 & $1-9-74$ & & $3-13-74$ & $1,320,000$ & 1,931 & 101 & 6.2 & 6.0 & 666,000 & 908,000 \\
\hline $40 *$ & $3-15-74$ & & $7-30-74$ & $1,400,000$ & 9 & 0 & 6.2 & 6.0 & 364,000 & $1,132,000$ \\
\hline 41 & $8-16-74$ & & $12-474$ & $1,500,000$ & 2,316 & 385 & 5.8 & 5.8 & 630,000 & 895,000 \\
\hline $42 * *$ & $12-17-74$ & & $4-15-75$ & $3,850,000$ & 2,116 & 119 & 5.8 & 6.0 & $1,018,000$ & $1,611,000$ \\
\hline 43 & $4-16-75$ & In & Service & $2,400,000$ & 2,712 & 174 & 5.7 & 5.8 & 937,000 & $1,823,000$ \\
\hline
\end{tabular}

*The reactor was shutdown during the entire run.

**New resin was placed in the demineralizer. 
Operating Manual

Changes which were made in the. BSR operating manual during this quarter are listed in Table 10 .

Table 10 ... Revisions..to .BSR Operating Manual (ORNL-TM-2676)

\begin{tabular}{|c|c|c|}
\hline Date & Section & Remarks \\
\hline $6-17-75$ & $\begin{array}{l}\text { Section } 11 \text { Auxiliary } \\
\text { Equipment }\end{array}$ & $\begin{array}{l}\text { Incorporates a checklist for } \\
\text { operation of the mobile } \\
\text { catwalk bridge. }\end{array}$ \\
\hline
\end{tabular}

\section{Efficiency Tests}

Tests were performed by. Inspection Engineering on the cell-ventilation filters. . Details are. given in Table 11 .

.Table..11. ‥Efficiency Tests Results, Filters

\begin{tabular}{lllc}
\hline Date & Unit & Type Test & Efficiency (\%) \\
\hline $6-12-75$ & North Bank & Elemental Iodine & 99.995 \\
$6-13-75$ & North Bank & Dioctyl Phthalate & 99.998 \\
$6-13-75$ & Center Bank & Dioctyl Phthalate & 99.998 \\
$6-13-75$ & South Bank & Dioctyl Phthalate & 99.996 \\
$6-26-75$ & North Bank & Methyl Iodide & 99.09 \\
$6-26-75$ & Center Bank & Methyl Iodide & 23.70 \\
$6-26-75$ & South Bank & Methyl Iodide & 44.85 \\
\hline
\end{tabular}


Special Programs

The University. Nuclear Engineer.ing Department Experiments

The. BSR was: used for training labs for university nuclear engineering s.tudents on seven occasions.. as described below.

Attenuation ...xperiment - The reactor was operated at variable power levels. (on May . 5, 6, 7.; .8 and .9;. 197.5) by, the Operations.. Division staff while the University of.Tennessee...tudents,... under the auspices of the Operations Division training supervisor; performed a neutron and gamma at tenuation experiment $\therefore$ Basically, the experiment.was -an exercise in measuring neutron and gamma levels from an operating nuclear reactor as a function of distance through light-water medium.

Xenon Buildup and Decay Experiment - On Apri1 11, 1975; and also on May 16, 1975, following operation at 2. Mw. to achieve xenon equilibrium, the power level of the BSR was reduced to $4 \mathrm{~kW}$ to begin an experiment for students from Mississippi State University and the University of Tennessee to study the buildup and decay of xenon in the BSR core.. The students performed all activities associated.with the experiment under the direct supervision of an Operations Division supervisor. The experiment, performed on a $24-\mathrm{hr}$-day schedule until completion,; was an exercise in: (1) maintaining the reactor critical at $4 \mathrm{kw}$, (2) determining the reactivity worth of a shim rod under varying concentrations of xenon, and (3) determining the reactivity worth of xenon. in the core as a function of time. 
Operation Activities

\begin{tabular}{|c|c|c|}
\hline Date & & Remarks \\
\hline $4-28-75$ & & 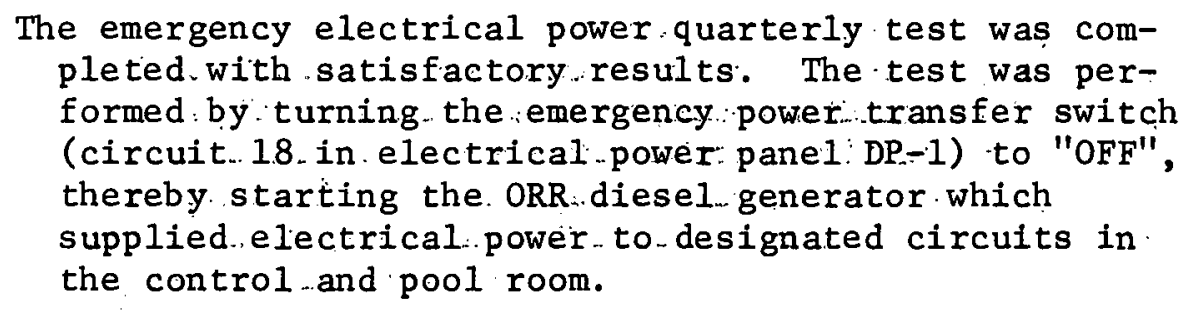 \\
\hline $5-1-75$ & & $\begin{array}{l}\text { The valve pit was inspected... The previously reported } \\
\text { water: leak: via. the grout-filled.. annulus in the } \\
\text { concrete wall for the exit primary water line } \\
\text { continues to leak from the pool into the valve pit. } \\
\text { as previously.reported. . The leak. rate is } \sim 10 \mathrm{gal} / \text { day. }\end{array}$ \\
\hline $5-1-75$ & & $\begin{array}{l}\text { The containment system quarterly functional checks were } \\
\text { performed..with satisfactory results. }\end{array}$ \\
\hline $5-20-75$ & & 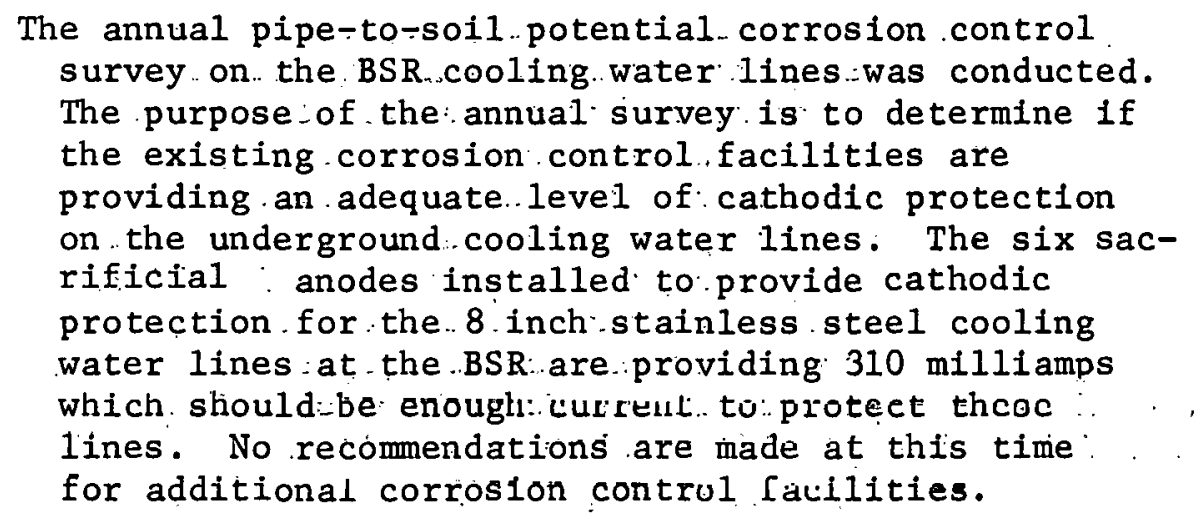 \\
\hline
\end{tabular}

\section{Shim-Rod Calibrations}

The BSR shim rods. were calibrated after core loading 28 had been established. The results are shown in Appendix.A. The. total worth of all six.rods was $11.560 \% \Delta \mathrm{k} / \mathrm{k}$. The operating limit requirement that the reactor be operated. with the ganged..rods. (al1. six) withdrawn at least 50\% of their worth thus requires the rods be $\geq 10.70$ in. withdrawn when the reactor becomes critical for power operation.". With rods 5 and 6 at 23 in. withdrawn, rods $1,2,3$, and 4. can be withdrawn. to 9.40.in. to comply with the same operating limit. Appendix. A.also shows : the comparison of rod worths for January, 19.71; .. October., 1971; ..January; 197.2; and September, 1974 . 
POOL CRITICAL ASSEMBLY

\section{Operations}

The PCA was used 66.3 hours as an experiment facility : for the benefit of nuclear engineering students from the University of Kentucky and Mississippi. State University... Operational activities. in preparing the facility for use included a check out of the reactor control instrumentation and preparation of the required loadings. The operational activities are listed in Table. 12...(Usage of Pool. Critical Facility).

Table.: 12... Usage of ..Pool. Critical Facility.

\begin{tabular}{|c|c|c|c|}
\hline Date & Operational Activity & Purpose & $\begin{array}{l}\text { Hours } \\
\text { Used }\end{array}$ \\
\hline $4-1-75$ & Training and reactor startups & $\begin{array}{l}\text { Training lab for the ORR- } \\
\text { BSR Reactor Controller } \\
\text { trainee. }\end{array}$ & 2.7 \\
\hline $4-7-75$ & $\begin{array}{l}\text { Established Core No. } 168 \text { to } \\
\text { obtain a..critical mass. } \\
\text { following the standard. } \\
\text { approach-to-critical. } \\
\text { procedure. }\end{array}$ & $\begin{array}{l}\text { Training lab for the } \\
\text { Mississippi State } \\
\text { University nuclear.. } \\
\text { engineering students }\end{array}$ & 11.9 \\
\hline $4-8-75$ & $\begin{array}{l}\text { Established Core, No...169 to } \\
\text { obtain a critical mass } \\
\text { following the standard } \\
\text { approach-to-critical... } \\
\text { procedure. }\end{array}$ & $\begin{array}{l}\text { Training lab for the } \\
\text { Mississippi State } \\
\text { University nuclear. } \\
\text { engineering students }\end{array}$ & 11.0 \\
\hline $\begin{array}{l}4-9-75 \\
\text { and } \\
4-10-75\end{array}$ & $\begin{array}{l}\text { Established Core No. } 77 \text { to } \\
\text { permit calibration of the } \\
\text { regulating rod and the } \\
\text { performance of the important } \\
\text { function experiment. }\end{array}$ & $\begin{array}{l}\text { Training lab for the } \\
\text { Mississippi state } \\
\text { University nuclear } \\
\text { engineering students }\end{array}$ & 12.5 \\
\hline $4-16-75$ & $\begin{array}{l}\text { Established Core No. } 170 \text { to } \\
\text { obtain a critical mass } \\
\text { following the standard } \\
\text { approach-to-critical } \\
\text { procedure. Establiahcd. } \\
\text { Core No. 171 to permit. } \\
\text { calibration of the reg- } \\
\text { ulating rod. }\end{array}$ & $\begin{array}{l}\text { Training lab for the } \\
\text { University of Kentucky } \\
\text { nuclear engineering } \\
\text { students. }\end{array}$ & 13.5 \\
\hline
\end{tabular}


Table 12. (continued)

\begin{tabular}{|c|c|c|c|}
\hline Date & Operational Activity & Purpose & $\begin{array}{l}\text { Hours } \\
\text { Used }\end{array}$ \\
\hline $4-17-75$ & $\begin{array}{l}\text { Established Core No.. } 172 \text { to } \\
\text { obtain a.critical mass. } \\
\text { following the standard.. } \\
\text { approach-to-critical... } \\
\text { procedure: Established } \\
\text { Core No.:173 to permit } \\
\text { calibration of the } \\
\text { regulating rod. }\end{array}$ & $\begin{array}{l}\text { Training lab for the } \\
\text { University of . Kentucky } \\
\text { nuclear engineering } \\
\text { students } .\end{array}$ & 14.7 \\
\hline
\end{tabular}




\section{Experiments.}

Experiments. were conducted at the PCA by. students.. from the Nuclear Engineering Departments. of Mississippi. State:University and the University of Kentucky as. indicated in Table 12.:. These. experiments are described briefly and were directly supervised by. the training-supervisor of the Operations Division.

Approach-to-Critical

To demonstrate. the technique. of:- assembling: a: reactor-core, a critical mass was loaded by the nuclear..engineering: students. following the standard approach-to-critical procedure.

\section{$\underline{\text { Regulating-Rod Calibration }}$}

A technique used in calibrating reactor control. rods. was demonstrated by using the period method in calibrating the regulating rod. The exercise was performed by the nuclear engineering students.

\section{Statistical Weight}

An experiment. was performed. to.. determine... the effect. of absorbers on the reactivity. as a function of position in a special fuel element located in the reactor core:. Using. guidelines.provided..by...the Operations supervisor, the experiment was performed by the nuclear engineering students. 
APPENDIX A

\section{INTRA-LABORATORY CORRESPONDENCE}

OAK RIDGE NATIONAL LABORATORY

July 17,1975

TO:

F. T. Binford

FROM: $\quad$ T. P. Hamrick

SUBJECT: Calibration of BSR Shim Rods

The BSR shim rods were calibrated following the refueling operation to establish BSR loading No. 28. The resulting reactivity worth curves are attached, along with a plot of excess reactivity remaining versus the ganged rod position of rods $1-4$. Loading 28 resulted in a core with $5.45 \% \Delta \mathrm{k} / \mathrm{k}$ excess reactivity.

As determined from this most recent calibration of the shim rods, the minimum position of the shim rods at critical are:

1. All six rods ganged at 10.70 inches withdrawn; and

2. Rods 5 and 6 at 23 inches withdrawn, rods $1-4$ ganged at 9.40 inches withdrawn.

Rod worths determined during the five most recent calibrations are compared in Table 1 below:

Table 1. Comparison of BSR Rod Worths (\% $\Delta k / k$ )

\begin{tabular}{crrrrr}
\hline Rod No. & Jan. & $\begin{array}{l}\text { Oct. } \\
1971\end{array}$ & $\begin{array}{l}\text { Jan. } \\
1972\end{array}$ & $\begin{array}{l}\text { Sept. } \\
1971\end{array}$ & $\begin{array}{l}\text { June } \\
1975\end{array}$ \\
\hline & 1971 & & & & \\
1 & 1.762 & 1.710 & 1.944 & 1.697 & 1.934 \\
2 & 1.914 & 1.690 & 1.864 & 1.873 & 1.259 \\
3 & 3.011 & 2.716 & 3.018 & 2.942 & 3.086 \\
4 & 3.010 & 2.714 & 2.962 & 2.966 & 2.931 \\
5 & 0.910 & 0.922 & 0.852 & 0.946 & 0.940 \\
6 & 0.928 & 0.866 & 0.872 & 0.937 & 0.910 \\
$1-4$ & 9.697 & 8.830 & 9.788 & 9.478 & 9.710 \\
$5-6$ & 1.829 & 1.788 & 1.724 & 1.883 & 1.850 \\
Total & 11.526 & 10.618 & 11.512 & 11.361 & 11.560 \\
\hline
\end{tabular}

11.526

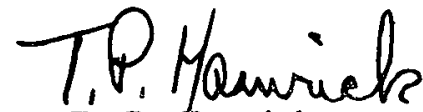

T. P. Hamrick

$\mathrm{TPH}: \mathrm{dsp}$

Attachments

cc: C. B. Gaither

S. S. Hurt

E. D. Lance

J. R. Thomas

BSR Control Room 


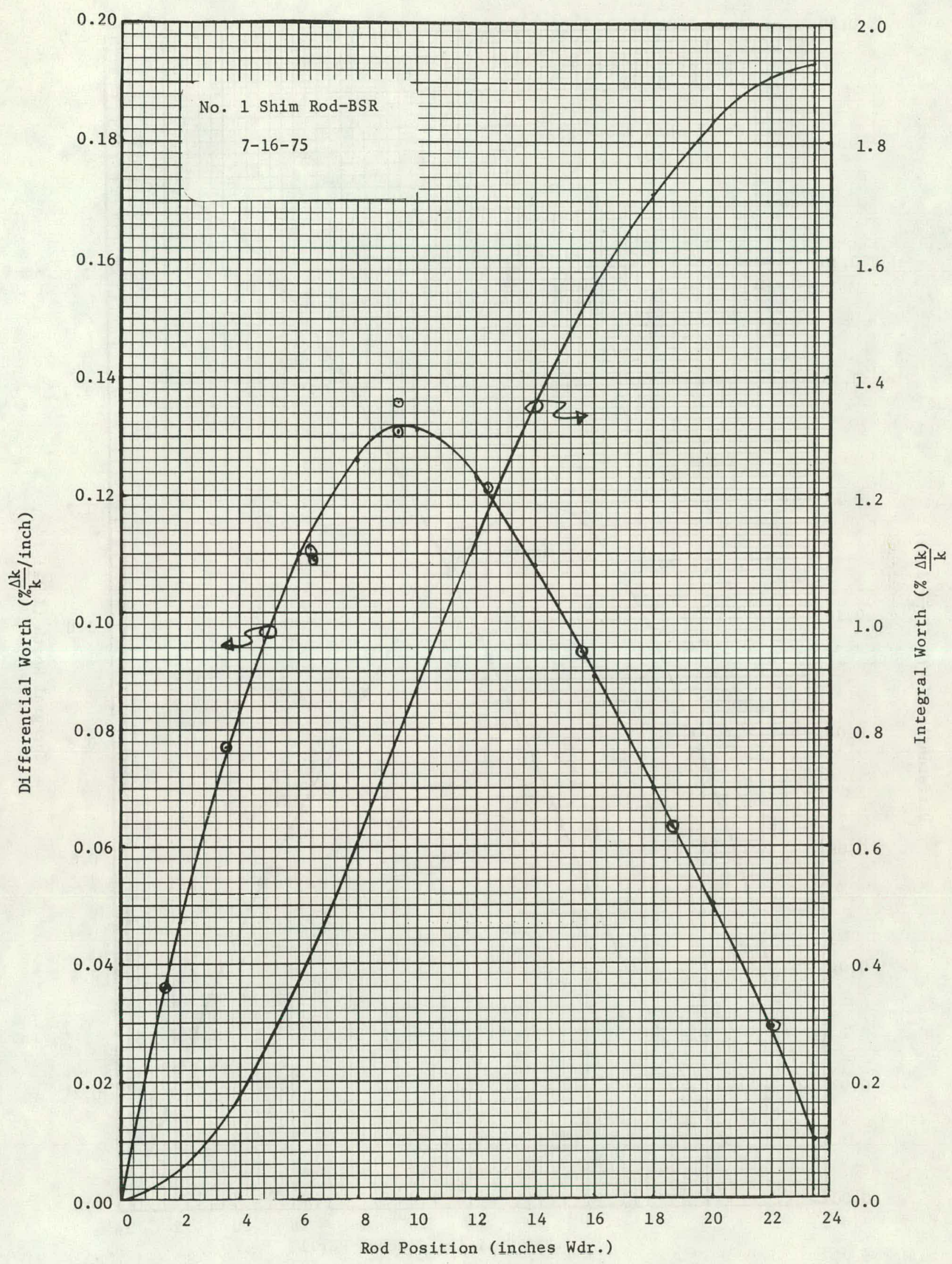




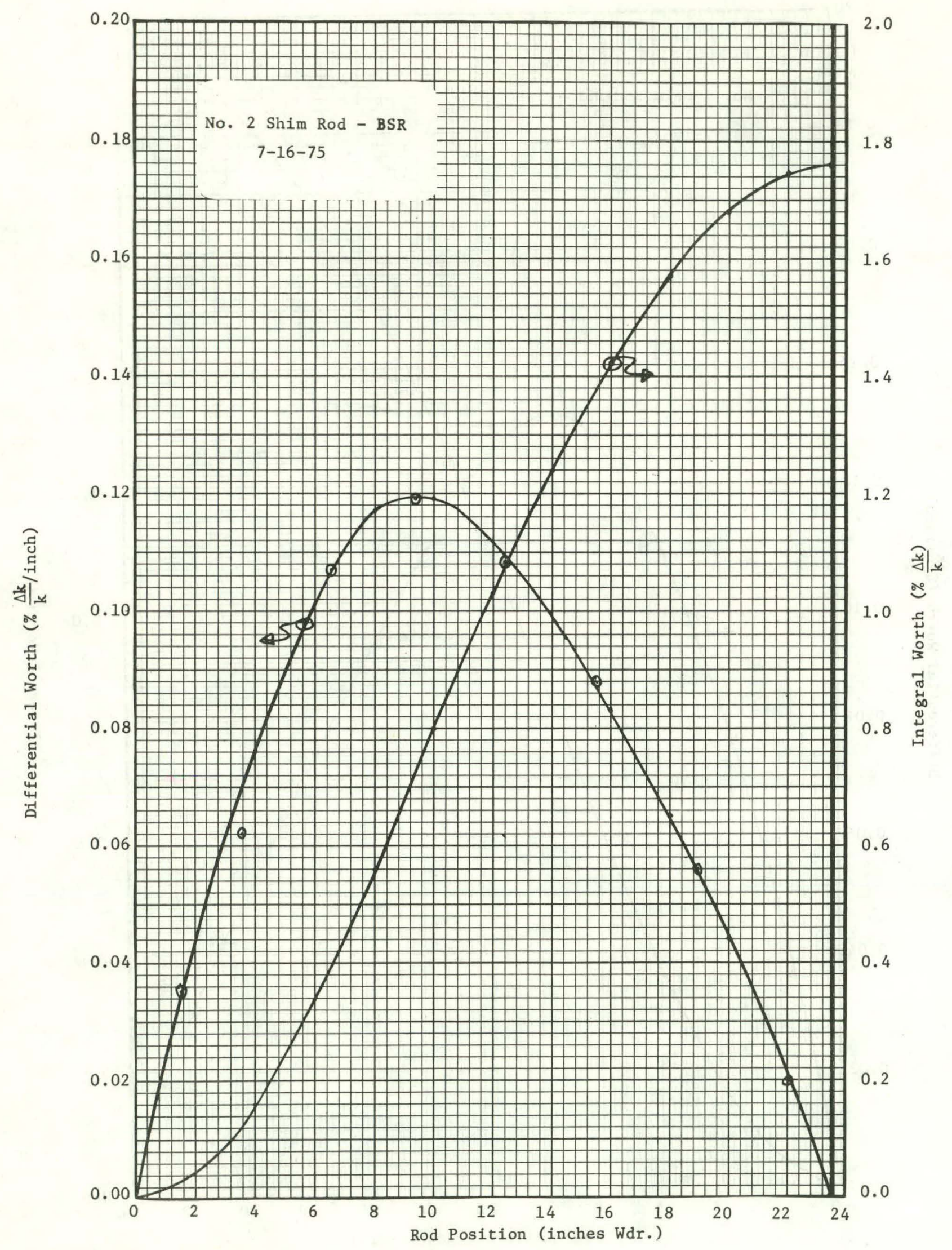




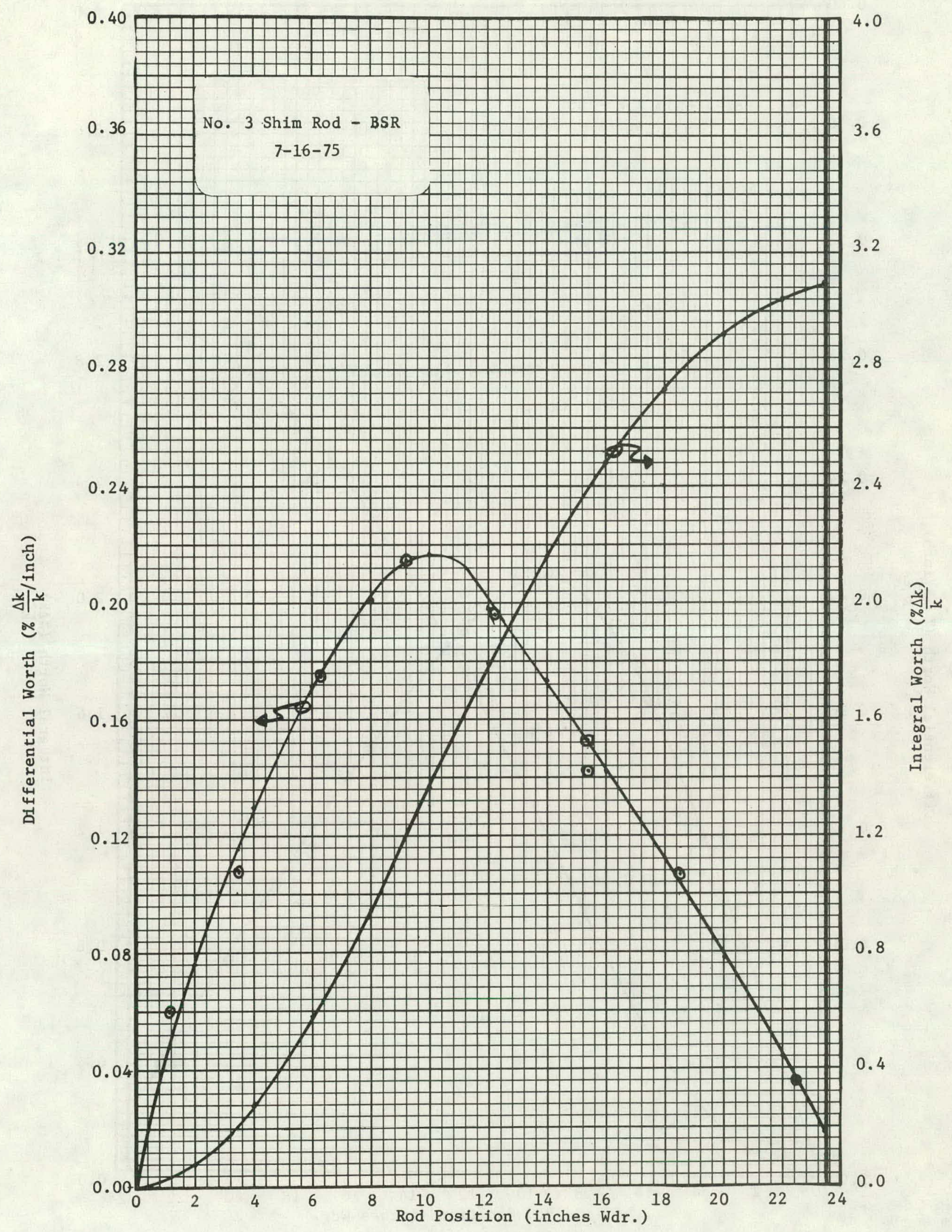




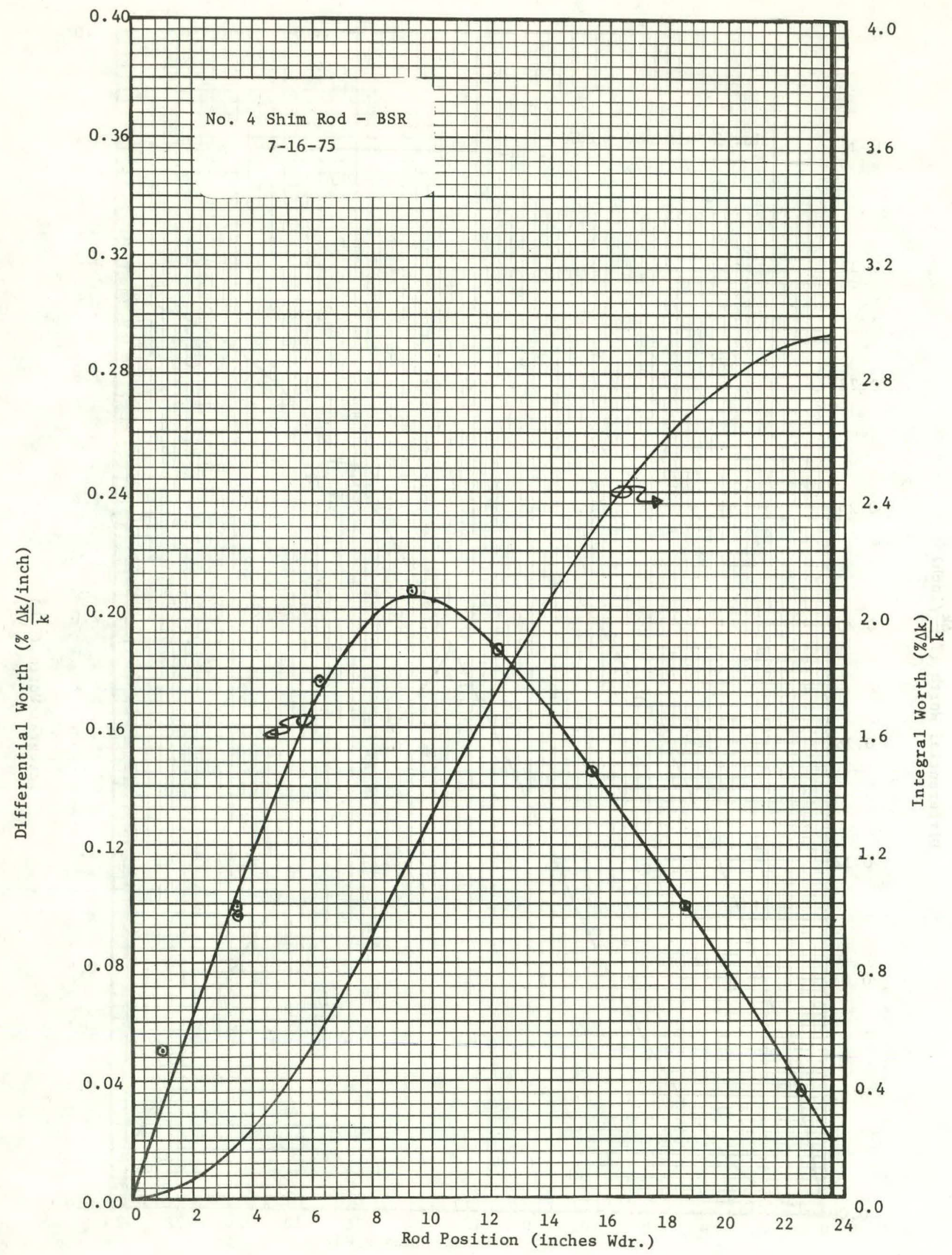




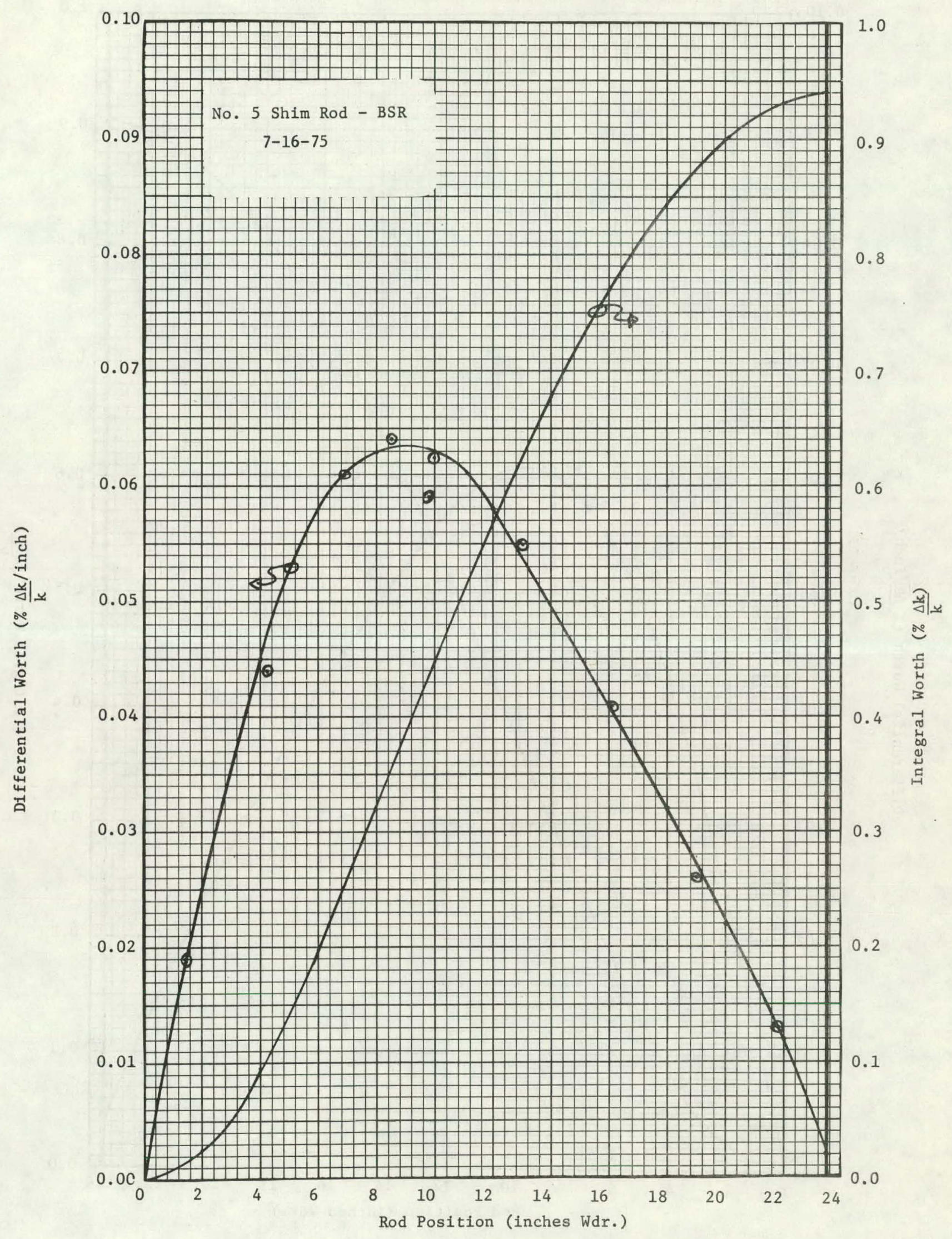




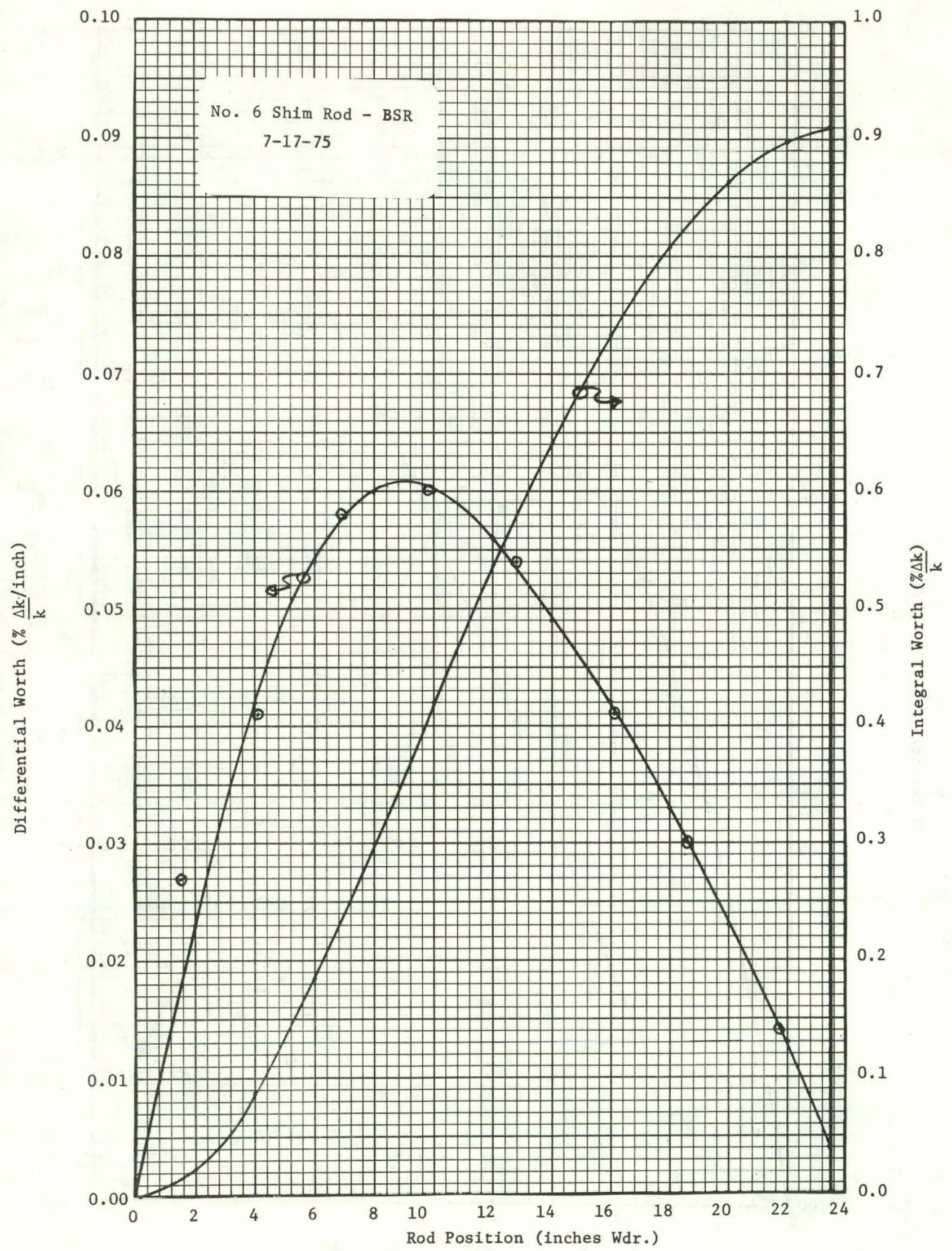




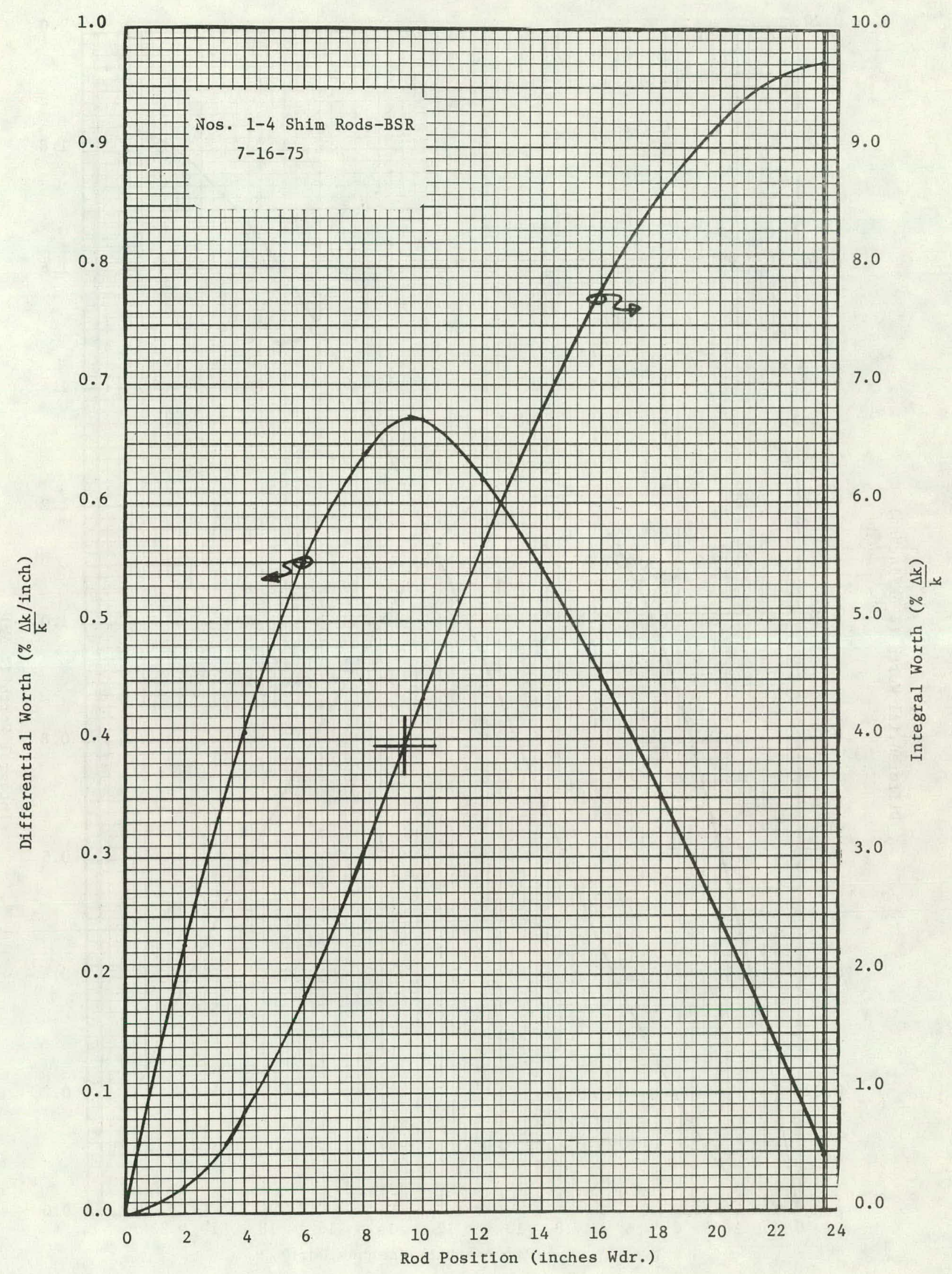




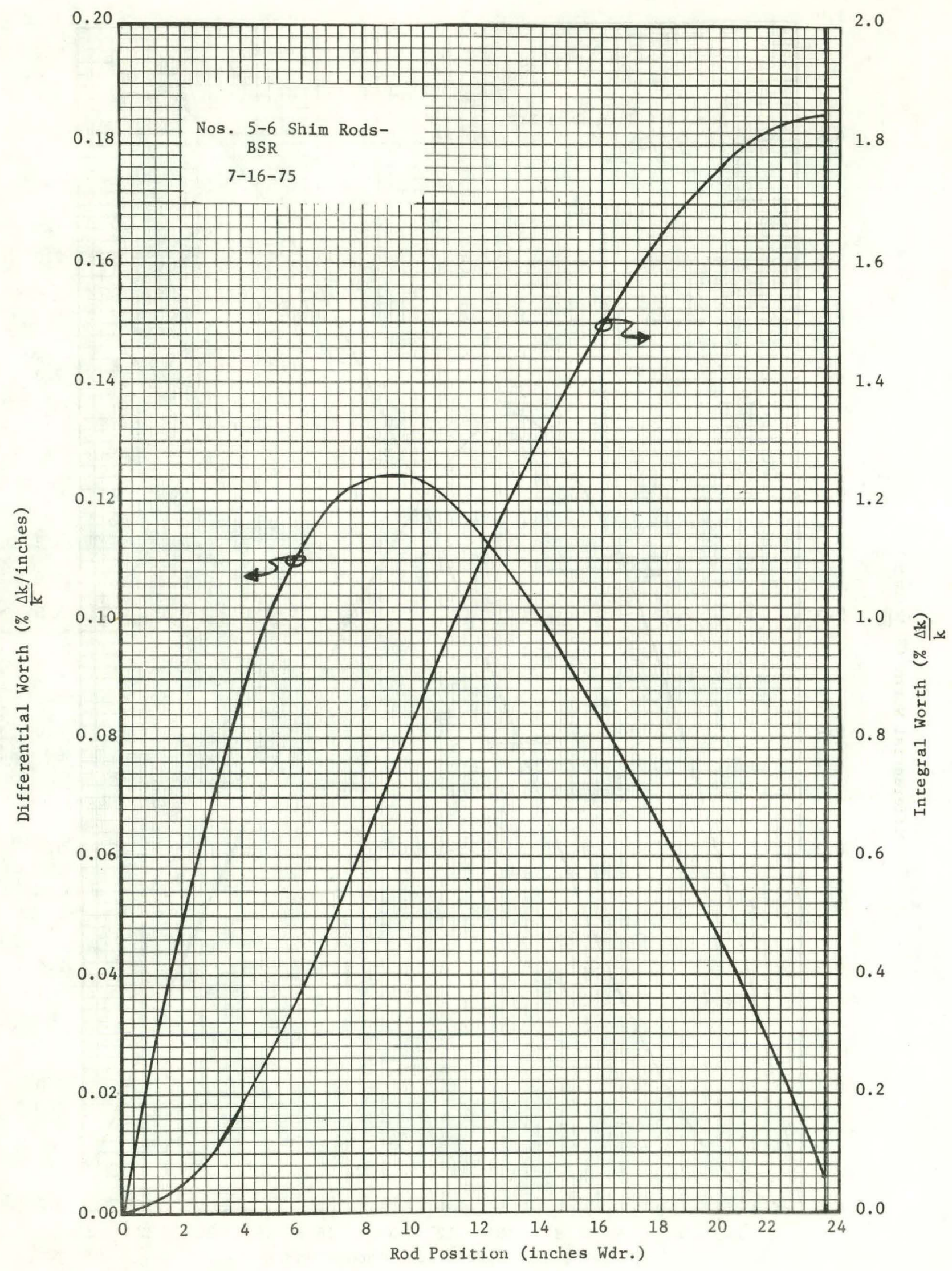




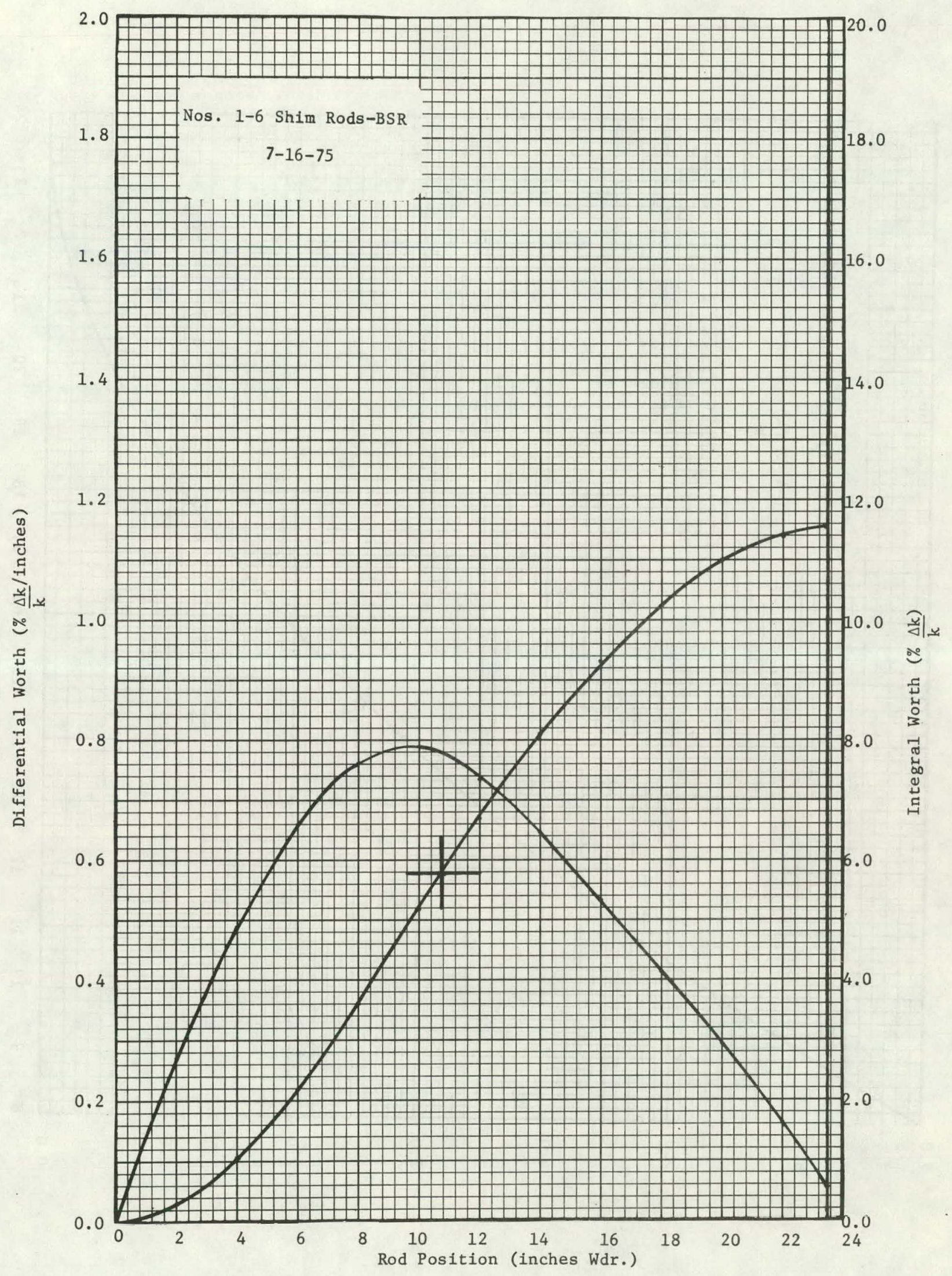




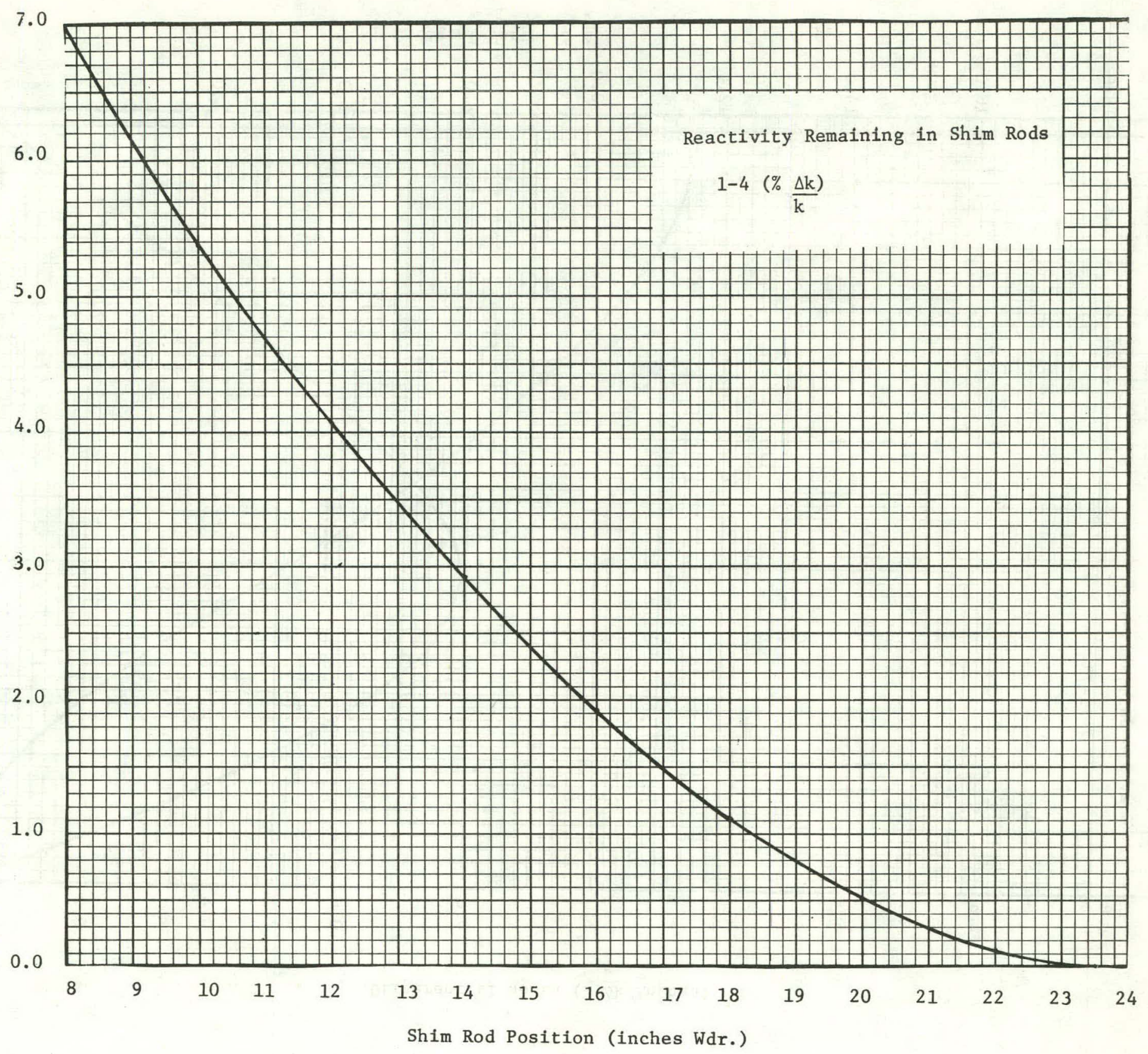




\section{APP.ENDIX B}

BSR SHIM ROD INSPECTION

I. Shim-rod identity BS-1, core position CP-62, shim rod No. 5.

A. Measurements previous.: to installation of : new : shim rod, January.4, 1967.

... 1:. Micrometer readings.- (out of water)

Flat Side

$\begin{array}{llll}\text { Bottom. } & 0.864 \text { in.. } & \ldots & 2.228 \text { in. } \\ \text { Middle: } & 0.867 \text { in. } & \ldots & 2.232 \text { in. } \\ \text { Top } & 0.867 \text { in. } & \ldots & 2.238 \text { in. }\end{array}$

2 ... Straight edge-inspection (out of water) --..-irregular surface to 0.010 in.

B.. Underwater inspection and measurements using oversized gauges along with feeler gauges and a straight edge, June 24, 1975.

1. 0.885 ...in. gauge minus feeler gauge (flat side); 2.260 in. gauge: minus -feeler gauge (edge side).

$\begin{array}{lll}\text { Bottom } & \frac{\text { Flat Side }}{0.879 \mathrm{in.}} & \frac{\text { Edge Side }}{2.246 \mathrm{in} .} \\ \text { Middle } & 0.879 \mathrm{in.} & 2.248 \mathrm{in} . \\ \text { Top } & 0.879 \mathrm{in.} & 2.248 \mathrm{in} .\end{array}$

2. Straight edge inspection of flat side - irregular surface to 0.012 in.

3.. Straight edge inspection of :edge: side-irregular surface to 0.012 .

4. Visual inspection using magnifying glass - no evidence of cracks.

II. Shim-rod identity BS-2, core position $\mathrm{CP} \div 64$, shim.rod No. 6 :

A. Measurements previous to installation of new shim rod, January 4 , 1967. 
1. .. Micrometer readings..(out of water)

\section{Flat Side}

Edge Side

$\begin{array}{lll}\text { Bottom . } & 0.873 \mathrm{in.} & 2.226 \mathrm{in} . \\ \text { Middle } & 0.871 \mathrm{in} . & 2.229 \mathrm{in.} \\ \text { Top .. } & 0.873 \mathrm{in.} & 2.235 \mathrm{in.}\end{array}$

2. Straight edge inspection (out of water) -- irregular surface to 0.005 in.

B. Underwater inspection and measurements using oversized gauges along with feeler gauges and a straight edge; June 25, 1975.

1. 0.895 in. gauge minus feeler gauge (flat. side); 2.270 in.

.. gauge minus. feeler-gauge (edge side).

\begin{tabular}{|c|c|c|}
\hline$\cdots$ & Flat Side & Edge S1de \\
\hline Bottom & $0.888 \mathrm{in}$. & 2.251 in \\
\hline Middle. & 0.887 in. & $2: 250 \mathrm{ln}$ \\
\hline Top & 0.888 in. & $2.250 \mathrm{in}$ \\
\hline
\end{tabular}

2. Straight edge inspection of flat side - irregular surface to 0.004 in.

3. Straight edge:inspection of :edge :side - irregular surface to 0.008 in.

4. Visual inspection using magnifying glass - no evidence of cracks :

III. Shim-rod identity BS-3; core position CP $\div 42$, shim rod No. 3 .

A. Measurements previous to installation of new shim rod; January 4, 1967.

1. Micrometer readings. (out of water)

$\begin{array}{lll} & \text { Flat Side } & \text { Edge Side } \\ \text { Bottom } & 0.861 \mathrm{in.} & 2.236 \mathrm{in} . \\ \text { Middle : } & 0.866 \mathrm{in.} & 2.235 \mathrm{in} . \\ \text { Top ... } & 0.866 \mathrm{in.} & 2.243 \mathrm{in} .\end{array}$

2. Straight edge inspection (out of water -- irregular surface to 0.005 in.

B. . Underwater inspection -and measurements using oversized gauges along with. feeler gauges and a straight edge, June 23, 1975. 
1. 0.885 in. gauge minus feeler gauge (flat side) $; 2.260$ in. gauge minus feeler-gauge (edge side).

$\begin{array}{rlll}\ldots . . . & \text { Flat Side } \ldots . . . & \text { Edge Side } \\ \text { Bottom... } & 0.882 \text { in. } & & 2.254 \text { in. } \\ \text { Middle.... } & 0.880 \text { in. } & & 2.25 .5 \text { in. } \\ \text { Top. . . } & 0.880 \text { in. } & & 2.254 \text { in. }\end{array}$

2. Straight.edge inspection of flat side... irregular surfaces to 0.005 .

3. . Straight edge. inspection of edge. side -.irregular surfaces to 0.014 .

4.. .. Visual inspection.. using magnifying glass.. - no evidence of cracks.

IV. Shim-rod identity BS-4, core position. CP-44, shim rod No. 4.

A. Measurements previous to installation of new.shim rod, January 4, 1967.

1. Micrometer readings: (out of water)

Flat Side

Bot.tom

Middle.

Top

0.860 in.

0.861 in.

0.862 in.
2. Straight edge inspection (out of water) $\rightarrow$ irregular surface to 0.003 in.

B. 'Underwater inspection and measurements. using oversized gauges along with feeler gauges and a.straight edge; .June 24, 1975.

1. 0.885 in. gauge minus ..feeler gauge (flat side); 2.260 in. gauge minus feeler gauge (edge side).

$$
\text { Flat Side }
$$

Botțom . 0.875 in.

Middle. $\quad 0.877$ in.

Top $\quad 0.877$ in.

2. Straight edge inspection of flat side - irregular surfaces to 0.012 : in.

3. Straight edge inspection of edge side - irregular surfaces to 0.010 .
Edge Side

2.233 in.

2.234 in.

2.231 in. 
4. Visual inspection .using.magnify.ing.glass -..no evidence of cracks.

V. Shim-rod identity BS-5, core position CP.-22, shim rod No. 1.

A. No measurements were made previous to installation of new shim rod.

B. Underwater. inspection and measurements using oversized gauges along with feeler. gauges and: a.straight.-edge., June 24; 1975.

1. 0.895, in gauge minus feeler gauge (flat side); 2.270 in. gauge minus feeler gauge (edge side).

\begin{tabular}{|c|c|c|}
\hline & Flat Side & Edge Side \\
\hline Bottom & 0.887 in. & 2.260 in. \\
\hline Middle & $0.883 \mathrm{in}$ & $2: 258$ in. \\
\hline Top & $0: 885$ in. & 2.259 in. \\
\hline
\end{tabular}

2. Straight edge inspection of flat side - irregular surfaces to 0.011 in.

3. Straight edge inspection of edge side - irregular surfaces to 0.009 in.

4. Visual inspection using magnifying glass - no evldence of cracks.

VI. Shim-rod identity. BS -6 , core position $\mathrm{CP}=24$, shim rod No. 2 .

A. No measurements were made previous to installation of new shim rod.

B. Underwater inspection and measurements .using oversized gauges along with. feeler gauges and a straight edge, June 25, 1975.

1. 0.885 in. gauge minus feeler gauge (flat side); 2.260 in. gauge minus feeler gauge (edge side).

$\begin{array}{lll} & \text { Flat Side } & \text { Edge Side } \\ \text { Bottom. . } & 0.879 \text { in. } \ldots & 2.250 \mathrm{in.} \\ \text { Middle. } & 0.881 \text { in. } . . . & 2.250 \mathrm{in.} \\ \text { Top. } & 0.882 \mathrm{in.} . & 2.251 \mathrm{in.}\end{array}$

2. Straight edge inspection of flat side - irregular surfaces to 0.004 in.

- 3. Straight edge inspection of edge side - irregular surfaces to 0.006 in. 


\footnotetext{
4. Visual inspection using magnify glass - no evidence of cracks.
}

Remarks: The shim rods, when.inspected..prior.to installation in the reactor, were found to..vary considerably... in thickness. and width. It is ver difficult to measure. the rods under, water. (micrometer versus oversized gauges: and. feeler: gauges); however, it is apparent that the dimensions have not changed more than a few thousandths of an inch. 
THIS PAGE

WAS INTENTIONALLY

LEFT BLANK 
INTERNAL DISTRIBUTION

1. R. G. Affel

2. D. S. Billington

3. C. D. Cagle

4. W. R. Casto

5. G. H. Coleman

6. J.A. Cox

7. W. A. Duggins

8. C. B. Gaither

9. E. D. Gupton

10. T. P. Hamrick

11. S. S. Hurt, III

12. L. P. Jernigan

13. E. B. Johnson

14. S. I. Kaplan

15. E. D. Lance

16. C. McBee

17. R. V. McCord

18. F. H. Neill

19. T. B. Nixon

20. L. C. Oakes

21. J. H. Pemberton

22. Herman Postma

23. M. E. Ramsey

24. W. H. Sides

25-26. J. R. Thomas

27. K. W. West

28." M. K. Wilkinson

29. F. W. Young

30-31. Laboratory Records, Department

32. Laboratory Records, ORNL R. C.

33-34. Central Research Library

35. ORNL Patent Office

EXTERNAL DISTRIBUTION

36. Research and Technical Support Division, ORO

37. K. M. Akhtar, Pakistan

38. R. D. Martin, University of Michigan

39. J. D. Randall, Texas $\Lambda \& M$ University

40. D. Sega 1, Israe1

41-42. Thomas A. Nemzek, ERDA, Washington, D. C.

43. Safety and Environmental Control Division

44-71. Technical Information Center, Oak Ridge 